\title{
Current deformation in Central Afar and triple junction kinematics deduced from GPS and InSAR measurements
}

\author{
Cécile Doubre, ${ }^{1}$ Aline Déprez, ${ }^{1}$ Frédéric Masson, ${ }^{1}$ Anne Socquet, ${ }^{2}$ Elias Lewi, ${ }^{3}$ \\ Raphaël Grandin, ${ }^{4}$ Alexandre Nercessian, ${ }^{4}$ Patrice Ulrich, ${ }^{1}$ Jean-Bernard De Chabalier, ${ }^{4}$ \\ Ibrahim Saad, ${ }^{5}$ Ahmadine Abayazid,${ }^{5}$ Gilles Peltzer, ${ }^{6}$ Arthur Delorme, ${ }^{4}$ Eric Calais ${ }^{7}$ \\ and Tim Wright ${ }^{8}$ \\ ${ }^{1}$ Université de Strasbourg, CNRS, IPGS-UMR 7516, F-67000 Strasbourg, France. E-mail: cdoubre@unistra.fr \\ ${ }^{2}$ Univ. Grenoble Alpes, CNRS, ISTerre, Grenoble, France \\ ${ }^{3}$ Addis Ababa University Arat Kilo Campus, Institute of Geophysics, Space Science and Astronomy, Addis Ababa, Ethiopia \\ ${ }^{4}$ Institut de Physique du Globe de Paris; UMR 7154, Paris, France \\ ${ }^{5}$ Observatoire Géophysique d'Arta - Centre d'Etudes et de Recherche de Djibouti, Djibouti \\ ${ }^{6}$ Earth and Space Science Department, University of California Los Angeles, CA, USA. Jet Propulsion Laboratory, California Institute of Technology, \\ Pasadena, CA, USA \\ ${ }^{7}$ Ecole Normale Supérieure, Dpt of Geosciences, UMR CNRS 8538, Paris, France \\ ${ }^{8}$ COMET, School of Earth and Environment, University of Leeds, United Kingdom
}

Accepted 2016 November 15. Received 2016 November 11; in original form 2016 May 10

\section{SUMMAR Y}

Kinematics of divergent boundaries and Rift-Rift-Rift junctions are classically studied using long-term geodetic observations. Since significant magma-related displacements are expected, short-term deformation provides important constraints on the crustal mechanisms involved both in active rifting and in transfer of extensional deformation between spreading axes. Using InSAR and GPS data, we analyse the surface deformation in the whole Central Afar region in detail, focusing on both the extensional deformation across the Quaternary magmato-tectonic rift segments, and on the zones of deformation transfer between active segments and spreading axes. The largest deformation occurs across the two recently activated Asal-Ghoubbet (AG) and Manda Hararo-Dabbahu (MH-D) magmato-tectonic segments with very high strain rates, whereas the other Quaternary active segments do not concentrate any large strain, suggesting that these rifts are either sealed during interdyking periods or not mature enough to remain a plate boundary. Outside of these segments, the GPS horizontal velocity field shows a regular gradient following a clockwise rotation of the displacements from the Southeast to the East of Afar, with respect to Nubia. Very few shallow creeping structures can be identified as well in the InSAR data. However, using these data together with the strain rate tensor and the rotations rates deduced from GPS baselines, the present-day strain field over Central Afar is consistent with the main tectonic structures, and therefore with the long-term deformation. We investigate the current kinematics of the triple junction included in our GPS data set by building simple block models. The deformation in Central Afar can be described by adding a central microblock evolving separately from the three surrounding plates. In this model, the northern block boundary corresponds to a deep EW-trending trans-tensional dislocation, locked from the surface to 10-13 km and joining at depth the active spreading axes of the Red Sea and the Aden Ridge, from AG to MH-D rift segments. Over the long-term, this plate configuration could explain the presence of the en-échelon magmatic basins and subrifts. However, the transient behaviour of the spreading axes implies that the deformation in Central Afar evolves depending on the availability of magma supply within the well-established segments.

Key words: Transient deformation; Mid-ocean ridge processes; Continental tectonics: extensional; Kinematics of crustal and mantle deformation; Africa. 


\section{INTRODUCTION}

The kinematics of Rift-Rift-Rift (RRR) triple junctions is usually studied using quantitative observations of long-term deformation (e.g. Searle 1980; Patriat \& Courtillot 1984). Non-stationary location and jumps of the branches, together with transient transform faults characterize triple junctions and their instability over time. Following Courtillot et al. (1984, 1987), the kinematics of a triple junction depend on the mechanical properties of the lithosphere and the importance of magmatism along spreading axes. In addition to being one of the rare examples of RRR junction, the Afar region is above water and thus an accessible case study to understand the short-term evolution of a triple junction. At the regional scale, the kinematics of this RRR junction has been the target of many studies focusing on the Neogene-Pliocene deformation that points out the importance of overlapping spreading axes generating a complex transfer zone with deformation distributed over a wide region (Manighetti et al. 1997; Wolfenden et al. 2004). However, dense measurements of the present-day deformation field are missing to draw the current kinematics of the triple junction, where active divergent plate boundaries and transfer zones are susceptible to rapid changes due both to the youth of the structures and to the discontinuous availability of magma supply (Courtillot et al. 1984; Patriat \& Courtillot 1984).

We present here an original combination of InSAR and GPS data acquired in Central and Eastern Afar, including the areas in Djibouti and Ethiopia. Unlike previous geological or geodetic studies focusing either on the Plio-Pleistocene tectonic evolution or on detailed monitoring of active rift segments, our measurements give a snapshot of the present-day deformation field in Afar, and of the current configuration of the triple junction in particular. We aim to identify the main structures currently accommodating the far-field plate motion, with a focus on the spreading axes, but also on the zone of the transfer of extensional deformation between the spreading axes, given the density of our measurements.

\subsection{The triple-rift junction in Afar}

Soon after the impingement of a mantle plume under the protoAfrican lithosphere and the related main volcanic phase between $\sim 31$ and $28 \mathrm{Ma}$, continental rifting started along the future axes of the Red Sea (RS) and Aden Ridge (AR), separating the Nubia and Arabia plates, and the Somalia and Arabia plates, respectively (Fig. 1 inset; Hoffman et al. 1997; Ebinger \& Sleep 1998; Courtillot et al. 1999). From $\sim 25$ to $20 \mathrm{Ma}$, while oceanic spreading developed in the RS and the AR, continental extension started in the Afar Depression (AD, Wolfenden et al. 2005). From $11 \mathrm{Ma}$, this extension has been driven by the rigid counter-clockwise rotation of the Danakil continental block and the clockwise rotation of the Ali Sabieh block to the south (e.g. Sichler 1980; Souriot \& Brun 1992; Eagles et al. 2002; Audin et al. 2004; Fig. 1 inset). The 1.5-km-thick sequence of basaltic lava, the Stratoïd series, dated from 0.4-4.4 Ma and covering two thirds of the AD surface (Varet 1975), hides older structures and prevents establishing any clear reconstructions of the kinematics of the triple junction before $4 \mathrm{Ma}$ within the AD.

The Holocene and recent volcanism in Afar is mainly concentrated along the northward propagation of the East-African Rift through the Mid-Ethiopian Rift (MER) and two narrow branches corresponding to the inland propagation of the Aden and the RS oceanic spreading ridges (Barberi \& Varet 1977; Manighetti et al. 1998).
In southern Afar, the northern tip of the MER consisted of a series of basins and volcanoes forming NNE-trending active rift segments (Hayward \& Ebinger 1996; Fig. 1).

In eastern Afar, the AR penetrates the Tadjoura Gulf along a series of $\mathrm{N} 120^{\circ}$-trending submerged volcano-tectonic segments (Manighetti et al. 1997) and the partly subaerial segment of AsalGhoubbet rift (AG), which started opening $\sim 0.9$ kyr ago (Fig. 1). This branch, forming the northeastern edge of the AD along the Danakil block, propagates further north, along the 0.4-0.5-Myr-old Manda Inakir (MI) rift segment separated from the AG rift by a large zone of distributed deformation along the Mak'Arrassou NS-fault system, accommodating the transfer of the extensional deformation between both rifts (Tapponnier \& Varet 1974; Manighetti et al. 1998, 2001; Fig. 1).

In northern Afar, the second branch of recent volcanic ranges corresponds to $\sim$ NS-trending rift segments, including the Erta Ale and the Manda-Hararo segments (Barberi \& Varet 1970, 1977; Manighetti et al. 1998).

\subsection{Plio-Pleistocene deformation in Central Afar}

The junction of the three spreading axes generates a wide zone of heterogeneous and distributed deformation. The two volcanic branches of the RS and the AR overlap and surround the region of Central Afar, whose surface consists of a series of horsts and amagmatic grabens (Fig. 1). Without major transform faults, the transfer of the extensional deformation is accommodated by the rigid movement of several crustal microblocks (Courtillot et al. 1984; Acton et al. 1991). Tapponnier et al. (1990) proposed the model of bookshelf faulting: the branches of RS and AR act as two spreading propagators leading to a large zone of dextral shear and the clockwise rotation of NW-striking elongated blocks separated by left-lateral NW-striking faults. Whereas Acton et al. (2000) propose three to four blocks, Manighetti et al. (2001) propose seven to eight. The decrease of the mean block rotation from $7-11^{\circ}$ in Eastern Afar and to 3-4 in Central Afar is interpreted as the result of the propagation of the spreading axes (Courtillot et al. 1984; Acton et al. 2000; Manighetti et al. 2001; Kidane et al. 2003; Audin et al. 2004).

In Central Afar, the 1.8-Myr-old Tendaho graben (TG) is the widest and longest basin in Afar (Fig. 1). It encompasses all the most southern structures perpendicular to the Arabia-Africa divergent motion in Afar. The boundary between the Afar rift systems and the MER is described as the Tendaho-Goba'ad Discontinuity (TDG), which has a clear signature in volume wave or ambient noise tomography through the first $100 \mathrm{~km}$ below the surface (Hammond et al. 2013; Korostelev et al. 2015) despite complex networks of both NNE- and NW-trending normal faults (Abbate et al. 1995). Within the sedimentary Awsa plains at the centre of the basin (Acton et al. 1991, 2000; Fig. 1), several NNW-trending subrifts are identified due to the topography and the presence of Holocene and historical lavas (Barberi \& Varet 1972). Whereas the Loma and Manda-Gargori (MG) subrifts are structured by systems of antithetic faults, the Kurub and the Dama Ale-Gob'ad subrifts do not present large tectonic structures on surface, but are mainly defined by the presence of a large volcanic edifice.

\subsection{Current deformation in Central Afar}

The global models of plate tectonics predict that the expected horizontal opening velocities across the three plate boundaries in Afar 


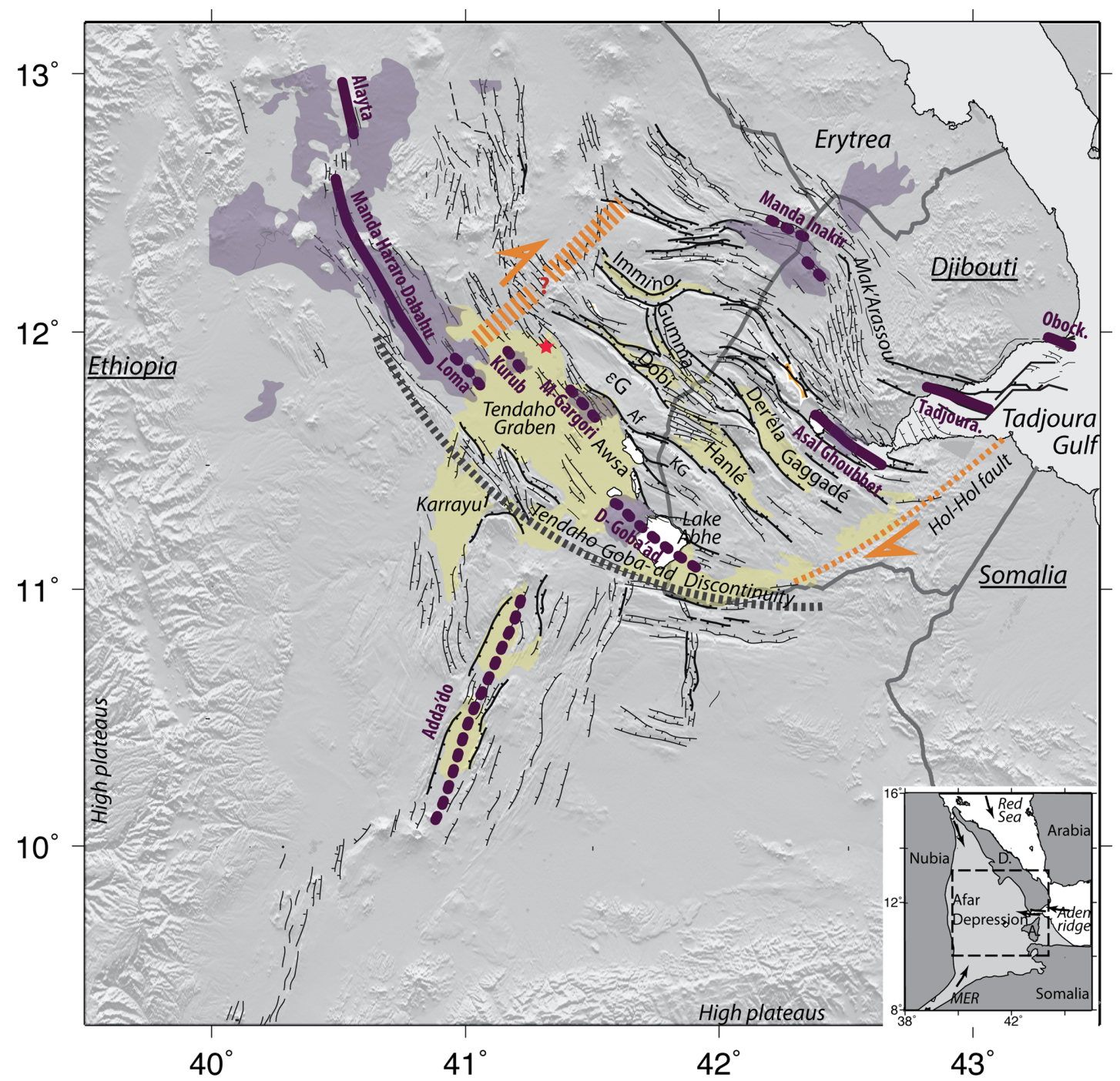

Figure 1. Structural map of the Afar Depression. The mapping of small and large faults indicated in thin and bold lines respectively has been made using the SRTM DEM and modified from Tapponnier et al. (1990), Hayward \& Ebinger (1996), Manighetti et al. (1998) and Jacques et al. (2011). The axes and names of the active rift segments are indicated by dark purple lines and recent lava flows in light purple areas (modified from Barberi \& Varet 1972). The sedimentary basins are in yellow. KG: Kadda Gamarri plateau; $\boldsymbol{\varepsilon}$ G: $\boldsymbol{\varepsilon}$ ounda Gamarri plateau, Af: Afambo fault system, Kar: Karrayu Basin. The dashed purple lines represent rift segments not recently affected by known dyking events. The red star corresponds to the location of the 1969 Serdo earthquake (Kebede et al. 1989). Inset: Regional map. Continental regions are in dark grey. D: Danakil block, A: Ali Sabieh block; MER: Mid-Ethiopian Rift.

are $\sim 5 \mathrm{~mm} \mathrm{yr}^{-1}$ along the EW direction for the Nubia and Somalia plates, $\sim 15 \mathrm{~mm} \mathrm{yr}^{-1}$ along the NE direction for the Nubia and Arabia plates and for the Somalia and Arabia plates (Jestin et al. 1994; Vigny et al. 2006; ArRajehi et al. 2009; McClusky et al. 2010; Déprez et al. 2013, 2015).

The current deformation in Afar has been studied extensively focusing on the rift segments of MH-D and AG, since they have been affected by active rifting sequences in 2005-2010 and 1978, respectively (e.g. Abdallah et al. 1979; Ruegg \& Kasser 1987; Wright et al. 2006; Vigny et al. 2007; Grandin et al. 2009). Tectonic, seismic and geodetic measurements have confirmed that the crustal extension in Afar occurred primarily along the rift segments and is mainly accommodated by transient magmatic intrusions within the crust, allowing the plate splitting of several metres.

Apart from these rifting episodes, little is known regarding the current deformation throughout the whole AD. In addition to the 1969 Serdo strike-slip event earthquake (Kebede et al. 1989), the 1989 Dobi seismic sequence revealed the activity of this amagmatic graben associated with fluid circulation within the crust (Noir et al. 1997; Jacques et al. 1999, 2011, Fig. 1). Both the regional diffuse seismic activity recorded by temporary and permanent, as well as local and worldwide networks (Jacques et al. 1999; Hofstetter \& Beyth 2003; Ayele et al. 2007a,b, 2015; Doubre et al. 2007; Ebinger et al. 2008; Keir et al. 2009a,b; Belachew et al. 2011; Grandin et al. 2011) and the surface velocity maps deduced from InSAR measurements (Doubre \& Peltzer 2007; Pagli et al. 2014) fail to better explain the spatial distribution of the current deformation in Central and Eastern Afar. Only a few patches of deformation signal have been identified, such as a seismic swarm in 2001 in the Mak'Arrassou transfer zone, associated with millimetric surface displacements across normal faults (Peltzer et al. 2007).

Except in Djibouti (Ruegg \& Kasser 1987; Vigny et al. 2007), few GPS measurements have been made with high resolution to describe the distribution of horizontal velocities distant in time and space from the rifting sequences. McClusky et al. (2010) focused on the motion of the Danakil block and its consequences on the total 
amount of extension within the AD. Kogan et al. (2012) examined the evolution of the velocities with respect to Nubia from the western high plateaus to the RS. However, the density of measurements in this area is too low to precisely quantify the respective role of these basins in the accommodation of the Arabia/Africa divergent motion.

\section{DATA PROCESSING}

\subsection{InSAR}

We created interferograms from SAR ENVISAT images acquired along two descending tracks (incidence angle: $\sim 20^{\circ}$, Fig. 2 ) over the 2003-2010 period. The processing of the eastern track (235) was conducted at full resolution in order to accurately study the displacements across the creeping faults in the AG rift segment
(Doubre \& Peltzer 2007). The processing of the western track (6) was conducted with a multilooking of 4 .

We followed the NSBAS chain (Doin et al. 2011) mainly based on the ROI-PAC software (Rosen et al. 2004) that includes an image coregistration step using topographic data (3 arcsec SRTM DEM), and estimates of the DEM errors and troposphere delay. For each track, the raw SAR data are converted into complex images (SLC) using the same Doppler centroid. A single master image is selected, based on both temporal and spatial baselines and on the difference of Doppler centroid in order to maximize the correlation between the images (Hooper et al. 2007). After co-registration (i.e. all the images in the same master geometry) and flattening, a significant part of the treatment consisted in the atmospheric corrections, since the atmosphere in Afar is significant in the InSAR signal (e.g. Doubre $\&$ Peltzer 2007). We corrected the interferograms from the stratified effects using ERA Interim data (Doin et al. 2009; Jolivet et al. 2011)

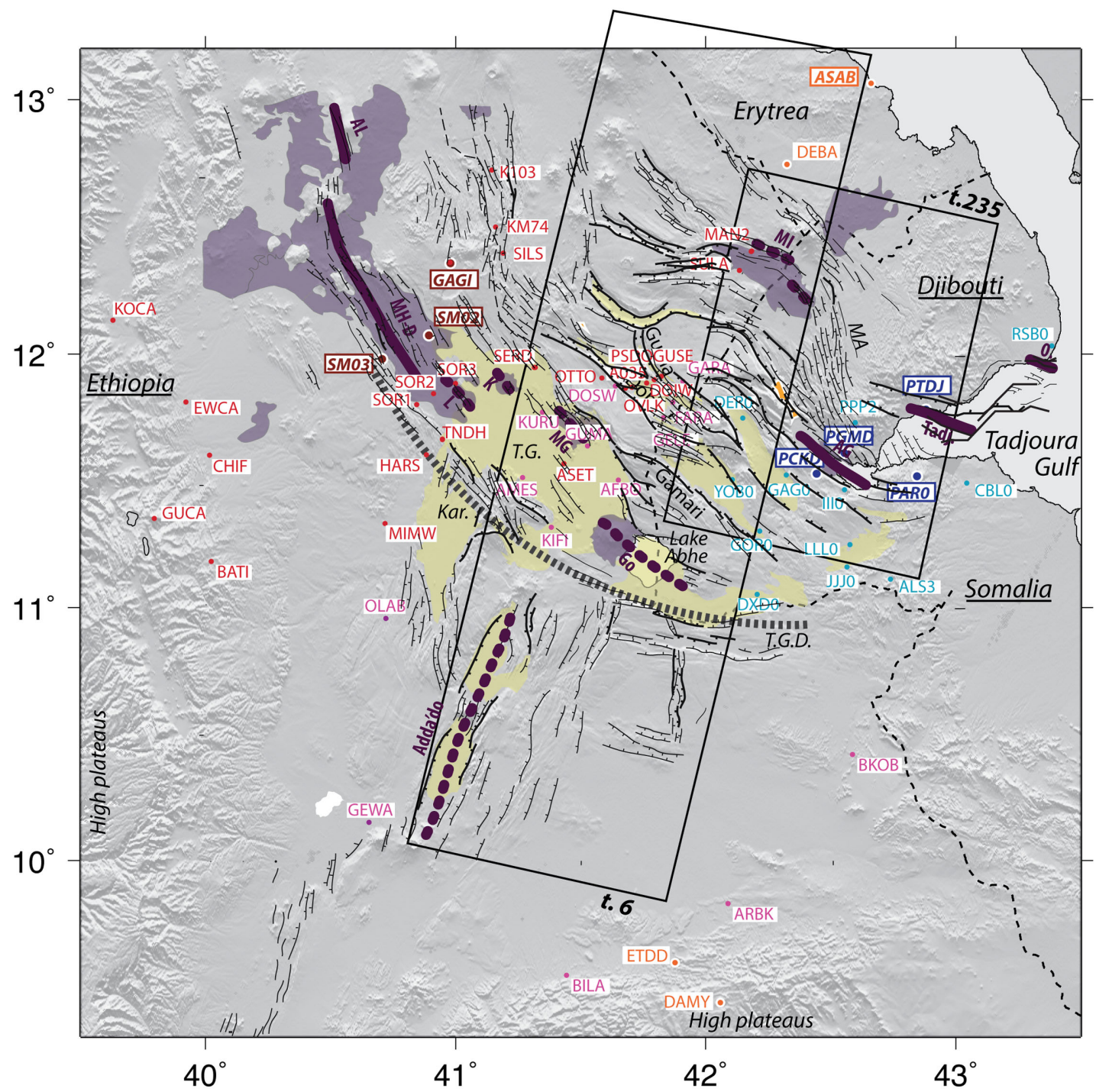

Figure 2. Network of GPS measured sites. See the caption of Fig. 1 for the background of the map. In light blue: sites from the regional Djiboutian campaign network; in dark blue: permanent GPS stations of the Geophysical Observatory of Arta; in red: sites from the regional Ethiopian campaign network; in orange: GPS stations for which semi-continuous acquisitions are taken into account. The two rectangles are the descending tracks of the Envisat images over Eastern and Central Afar. The rift segments are AL: Alayta rift segments, MH-D: Manda-Hararo-Dabbahu (also called Manda-Hararo northern section in other works), MH-T: Manda-Hararo-Tendaho (also called Manda-Hararo-Goba'ad or Tendaho graben in other works), O: Obock, Tadj: Tajoura, AG: Asal-Ghoubbet, and MI: Manda Inakir. The subrifts are L: Loma subrift, K: Kurub subrift, MG: Manda Gargori subrift and DG: Dama Ale-Goba'ad subrift. MA: Mak'Arrassou transfer zone, T.G.D.: Tendaho-Gob'ad Discontinuity. 


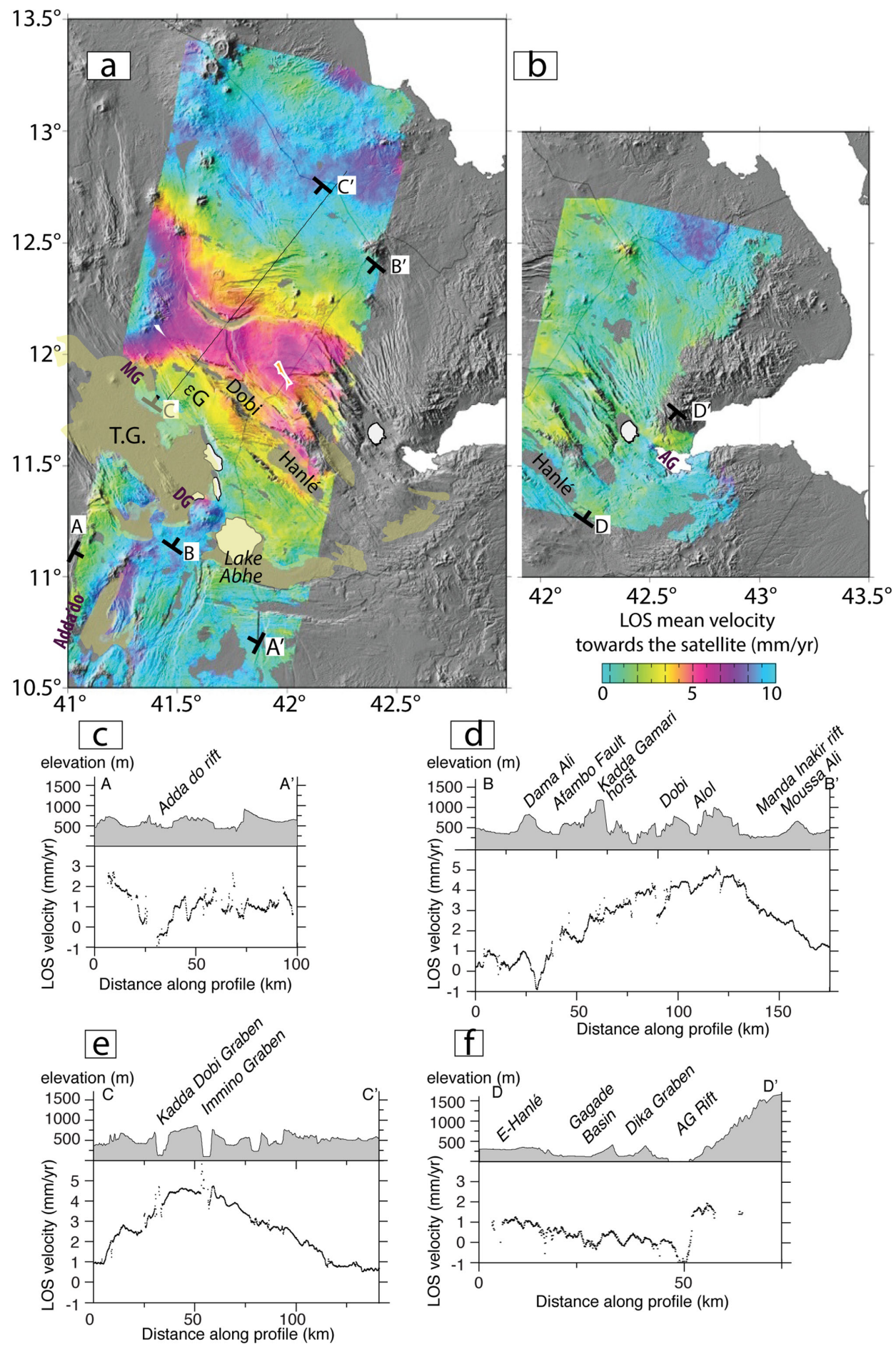

Figure 3. Mean LOS velocity from Envisat images acquired along the two descending tracks covering Afar. (a) Stack of 17 interferograms along the descending track 6. (b) Stack of 472 interferograms along the descending track 235. (c)-(e) Topography and mean LOS velocity along the $\mathrm{AA}^{\prime}, \mathrm{BB}^{\prime}$ and $\mathrm{CC}^{\prime}$ profiles indicated in (a). (f) Topography and mean LOS velocity along the DD' profile indicated in (b).

and by applying an empirical linear correction for the atmospheric delay correlated to the topography (Beauducel et al. 2000). We took advantage of the DEM correction tool included on the NSBAS chain in order to enhance the unwrapping quality (Ducret et al. 2013). The interferograms are then filtered and unwrapped. In order to obtain the mean velocity field and to mitigate the turbulent atmospheric noise (e.g. Peltzer et al. 2001), stacks are computed with 472 and 17 interferograms for the tracks 235 and 6, respectively (Fig. 3).

\subsection{GPS}

We used GPS data collected during several campaigns conducted both in Ethiopian and Djiboutian Afar. Table 1 presents the dates of measurements for each site. In addition to measurements available on the UNAVCO website (Calais \& Buck 2007; Calais 2008, 2009; Nooner et al. 2009; Kogan et al. 2012; Hamling et al. 2014; Pagli et al. 2014) and on the French GPS archive website GPScope 
Table 1. Location, magnitude of velocity components with respect to Nubia fixed (Déprez et al. 2015), dates of measurements for the sites in Afar. The last columns indicate if the velocity is included for the determination of the strain tensor (last column) and for both the determination of the strain tensor over the interdyking period and the block modelling (second to last column).

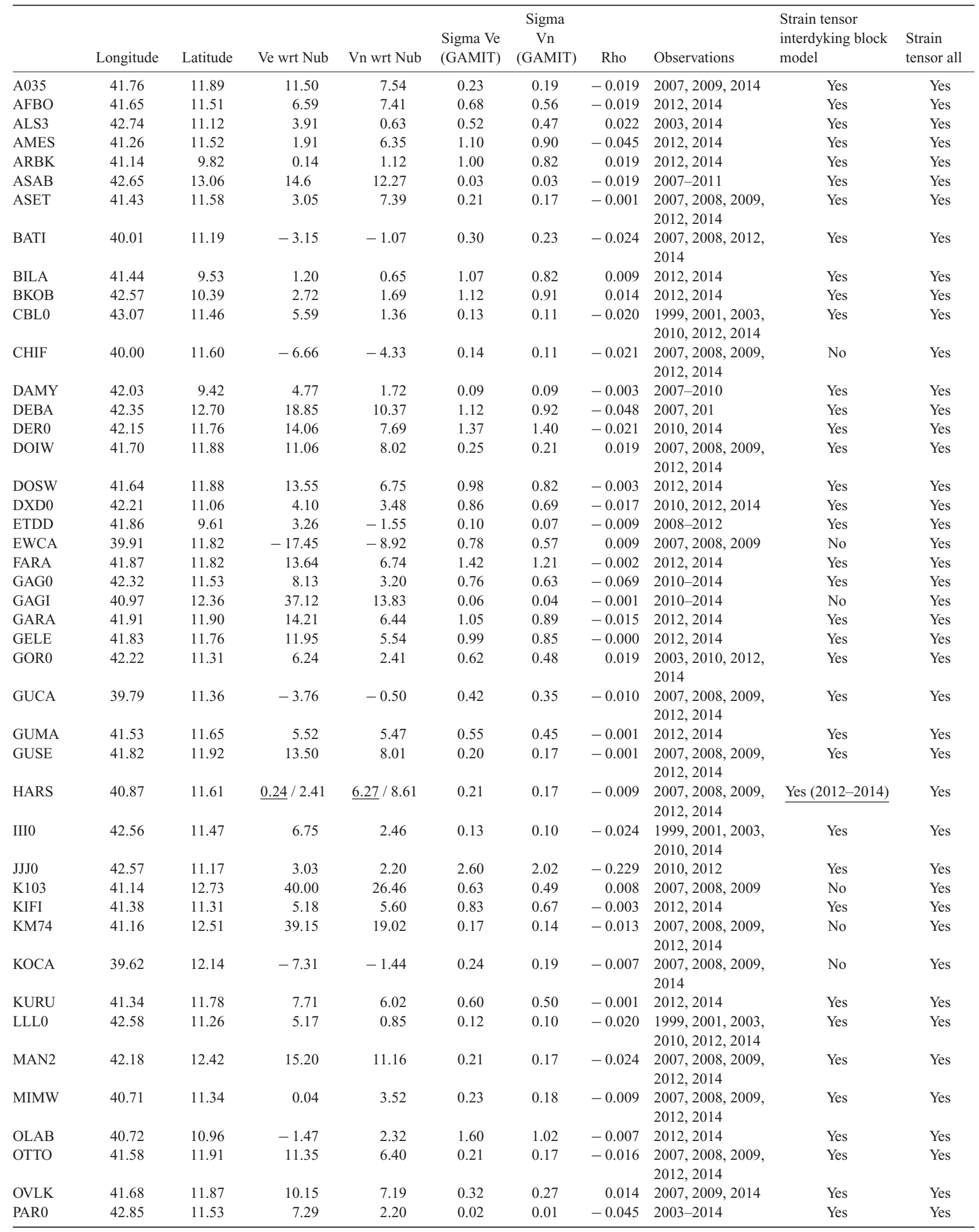


Table 1. (continued.)

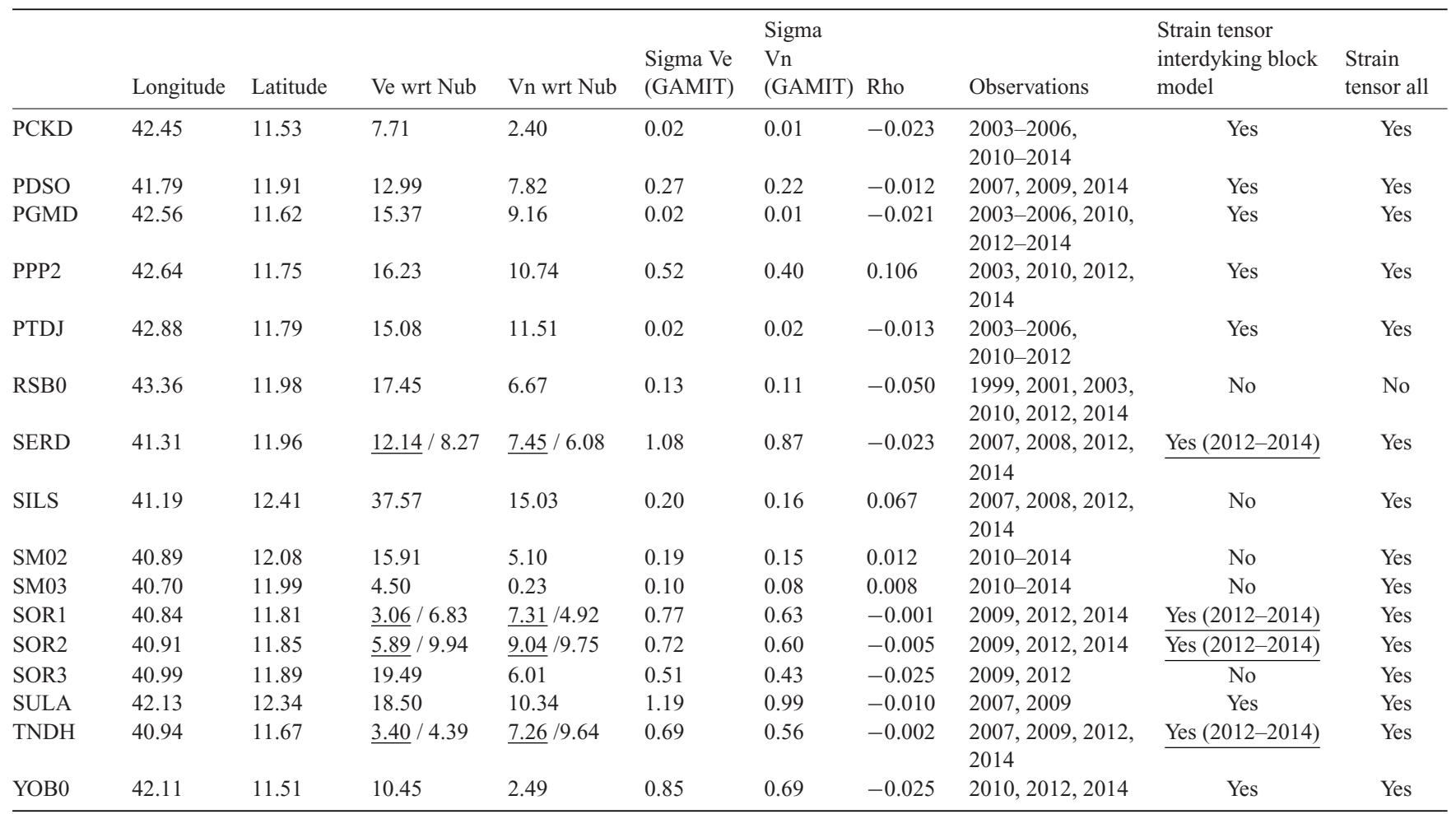

(Vigny et al. 2006, 2007), we re-measured the sites belonging to the Ethiopian network in 2012 and 2014, densified by 15 new sites (forced centring) in order to obtain a continuous and homogeneous velocity field between the existing networks. This also allowed us to describe the kinematics over the whole region, taking into account the limitations related to the field conditions and accessibility (Fig. 2). Therefore, we installed five sites within the southern part of the Tendaho Graben (AMES, KIFI, KURU, GUMA and AFBO), four sites along the road from Dobi to Asab and near the western Djiboutian border (DOSW and GELE, FARA, GARA, respectively), one site in southern Afar (OLAB), and three sites from the southern Djibouti border to the southern large scarp bounding the high plateaus of Dire Dawa/Harrar region (BILA, ARBK and BKOB). Measurements of the Djiboutian network have been conducted in 1999, 2001, 2003, 2010, 2012 and 2014 (Vigny et al. 2006, 2007; Doubre et al. 2014). In addition to these campaign measurements, we included 10 local permanent cGPS stations, 5 in Ethiopian Afar (ETDD, DAMY, GAGI, SM02 and SM03), 4 in Djiboutian Afar (PAR0, PTDJ, PGMD and PCKD) and one in Eritrea (ASAB).

We processed the GPS data using the GAMIT/GLOBK software version 10.5 (King \& Bock 2010), which led to daily position timeseries and absolute velocity with respect to ITRF2008 for each station. In order to stabilize the system, we included in the processing a selection of 9 IGS stable cGPS stations around the world (ONSA MAS1 ZIMM JOZE KIT3 POTS HRAO SUTH NKLG). Eventually, we represent the GPS velocity field by rotating the velocity values with respect to the Nubia plate determined from our processing (lat: $50.2013^{\circ} \mathrm{N}$; lon: $-81.3550^{\circ} \mathrm{E}, 0.26876^{\circ} \mathrm{Myr}^{-1}$, as well presented by Déprez et al. $(2013,2015)$ for the large scale) since this pole is more constrained than the one of either the Somalian or the Arabian Plate (Figs 4 and 5).

\subsubsection{Derivation of the strain rate field}

From this determination of the horizontal velocity field, we first look at the strain and rotation rates over Central Afar where the velocity data are distributed homogeneously. By assuming that the deformation is distributed along the whole baseline and considering the baseline length variation for each station couple of the geodetic network, we calculate the velocity gradient (Spakman \& Nyst 2002; Masson et al. 2014). Compared to other methods, such as triangle or grid-based approaches (Wu et al. 2011), the main advantage of this method is the decreased dependence on both geometry and quality of the geodetic field, since all possible station pairs are included in the inversion. Using the velocity gradient, we calculate the strain rate tensor and the rotation rates, independently of any reference frame. The calculation grid corresponds to $0.2^{\circ}$-wide cells, with the node location chosen at relevant places (rift zones, main faults, etc.) that compelled us to use one grid for the western part and separate one for the eastern part. We did not apply any smoothing factor and the covariance matrix of the a priori model is diagonal with a constant value of $1 \times 10^{-7} \mathrm{yr}^{-1}$, the order of magnitude of the deformation expected within the study area. The north and east velocity uncertainties are fixed to $1.5 \mathrm{~mm} \mathrm{yr}^{-1}$.

Two inversions have been processed (Fig. 6). The first one is dedicated to the steady state deformation in Central Afar., that is the deformation affecting the region during interdyking period. To do so, we selected sites by rejecting data encompassing transient deformation clearly visible in the GPS time-series. This concerned sites located near the dyking 2005-2010 intrusions in the $\mathrm{MH}-$ D segment (KOCA, EWCA, CHIF, K103, KM74, GAGI, SM02 and SM03). For sites located at the southern tip of the segment (HARS, SERD, SOR1, SOR2, SOR3 and TNDH), we only rejected data in the time-series acquired during the co-dyking period (see 


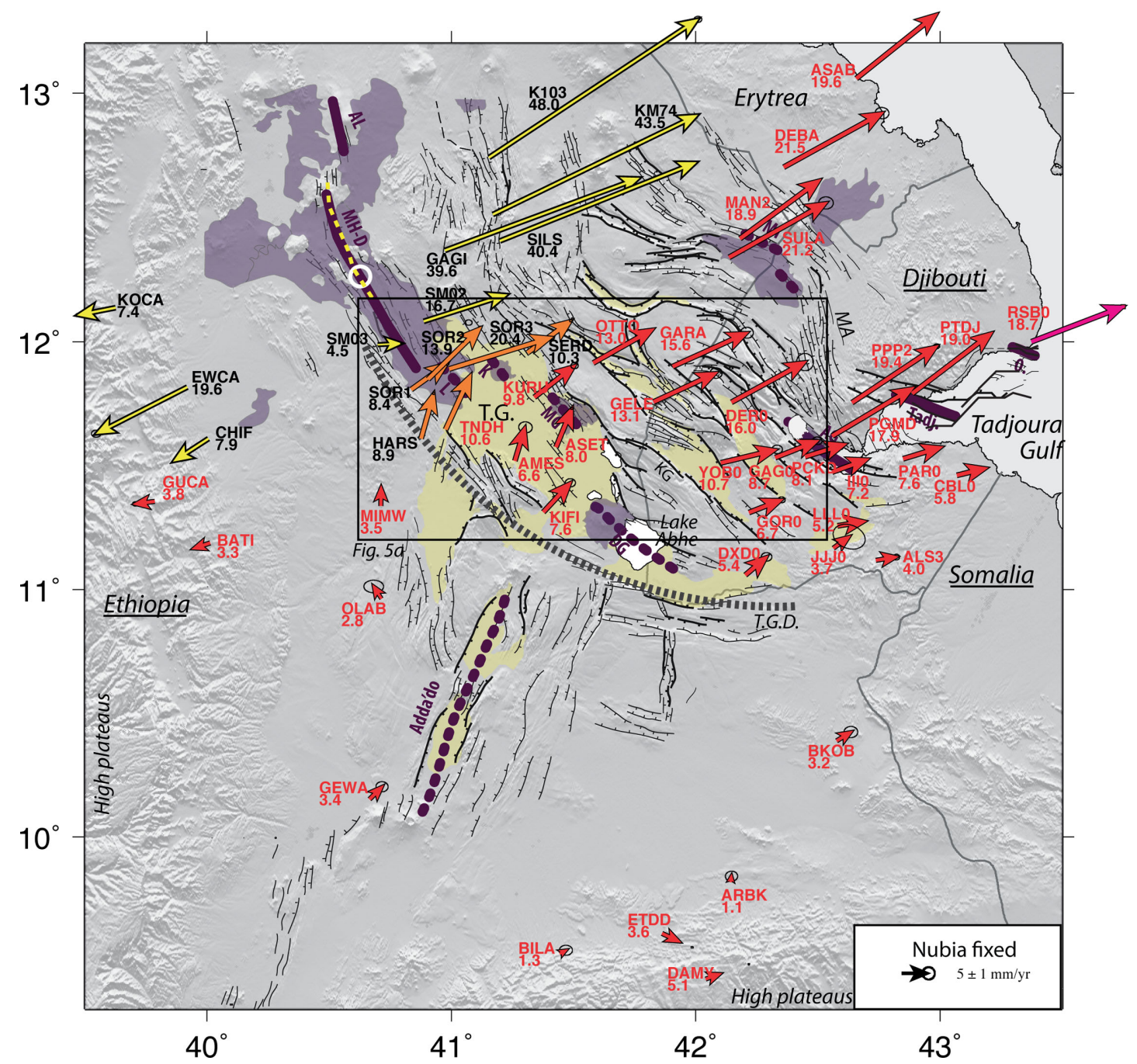

Figure 4. GPS velocity field in Afar. See the caption of Fig. 1 for the background of the map. The dashed yellow line and the white circle correspond to the location of the 2005-2010 sequence of intrusions within the MH-D rift segment and the main magma source feeding the intrusions deduced from previous works, respectively (e.g. Grandin et al. 2009, 2011; Hamling et al. 2009; Belachew et al. 2011). The whole set of velocities are used for the strain tensor inversion presented in Fig. 6(a), except for the site RSB0 as mentioned in the text (Section 2.2). For the interdyking period, the orange velocities obtained only for the period of 2012-2014 (values indicated in Table 1) and the red velocities are included in the strain tensor inversion presented in Fig. 6(b).

Table 1). On the contrary, the second inversion aimed to focus on the deformation in Central Afar when the large opening occurs in the MH-D segment by considering all the data. This inversion has to be consider carefully because both amplitudes and directions of the velocities at the specified stations are transient, and the deduced rotation rates and strain tensors highly depend on them. However, it indicates what could be the effect of the large opening at the MH-D segment on the deformation in Central Afar, and in particular on the mechanism of bookshelf faulting within the shear zone induced by the opening ridges. We note, that for both inversions, we excluded from the data set the measurements from the site of Obock (RSB0), at the entrance of the Tadjoura Gulf, whose position time-series exhibits a clear change in $\sim 2009$, and deserves an individual study of this zone beyond the scope of this article.

\subsection{Block models inversion}

In order to discuss the previous results and investigate the kinematics of this triple junction, in particular the potential location of block boundaries in Central Afar together with an estimate of coupling depth along these boundaries, we construct simple block models using Tdefnode software (McCaffrey 1995, 2002, 2009). In the following cases, the block boundaries are associated with an irregular grid of points along a fault plane with a vertical dip. At each node, defined by longitude/latitude/depth coordinates, we estimate the locking depth, that is the depth to which the coupling on the dislocation is 1 . The inversion is a two-step process, following a grid search method and a simulated annealing method.

We increase the uncertainties of the east and north components of velocities given by the GAMIT/GLOBK software to a value of $1.5 \mathrm{~mm} \mathrm{yr}^{-1}$ (similar to the strain rate inversion), given that the software largely underestimated the uncertainties from velocities deduced from campaign measurements. By doing so, we prevent abnormally high constraints for the inversions and in particular enable a wide investigation in the model space. We only consider the velocities considered previously as the "interdyking " velocities, in order not to introduce large horizontal vectors which would lead to an unstable inversion. The motion of the Arabian plate is imposed using Altamini et al. (2008), and the motion 


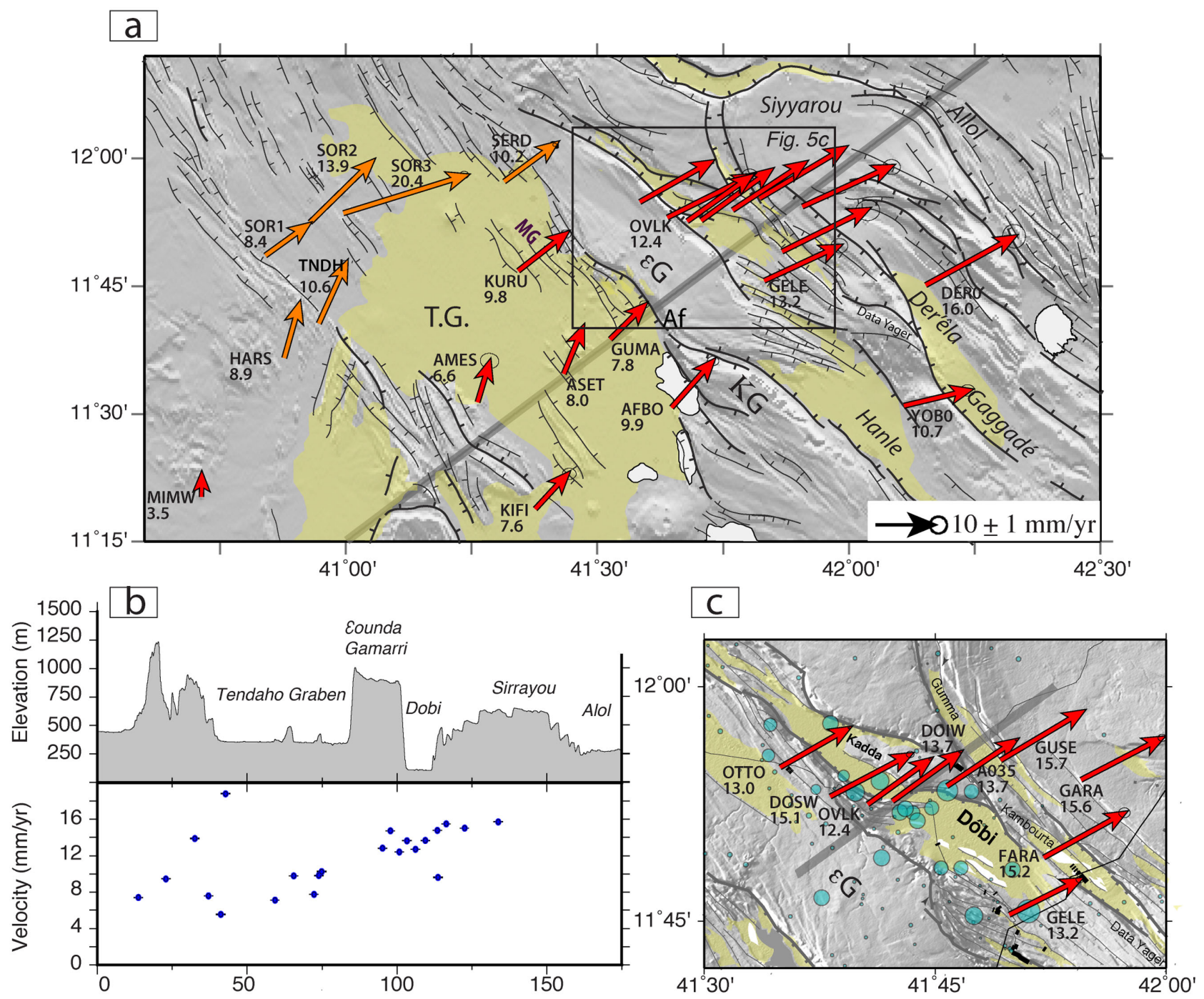

Figure 5. (a) GPS velocity field in Central Afar. See the caption of Fig. 1 for the background of the map. The black rectangle is the location of the area in (c). Refer to caption of Fig. 4 for explanations on colours of velocities. (b) Topography and horizontal velocity along the NW-trending profile. (c) GPS velocities and location of the events of the 1989 Dobi sequence (Jacques et al. 1999).

of the Somalia and Nubia using Déprez et al. (2013, 2015; see Table 1).

\section{COMPARATIVE ANALYSIS OF VELOCITY FIELD, STRAIN RATE TENSOR AND ACTIVE STRUCTURES IN CENTRAL AFAR}

\subsection{General description of the geodetic observations}

In order to study the spatial distribution of the current deformation in Central Afar, we analyse the InSAR maps of surface mean velocity (Fig. 3) together with the GPS velocity field (Figs 4 and 5) and the strain rate and the rotation rate fields (Fig. 6).

Considering the geometry of SAR acquisitions and the direction of the horizontal GPS velocities (Figs 4 and 5), most of the deformation presented in the maps and profiles of the ground mean velocity along the line of sight (LOS; Fig. 3) corresponds to vertical displacements. The lack of sharp gradients in the InSAR data and the regular low horizontal velocity gradient from the SW to the
NE (Fig. 4) point out that no shallow structure is creeping at a rate exceeding a few $\mathrm{mm} \mathrm{yr}^{-1}$. A striking large-scale feature of this GPS velocity field is the overall clockwise rotation from the southwestern part to the eastern part of the studied area. To the northeast, large GPS velocities at the southern part of the Danakil block are consistent with the Arabia plate motion (>19 $\mathrm{mm} \mathrm{yr}^{-1}$, Fig. 4; McClusky et al. 2010). The InSAR velocity maps encompass residual short wavelength variations due to the turbulent tropospheric content in this region that are not compensated by the low number of interferograms used for the calculation of the mean velocity, especially along the western track. At the northwestern corner of the western track (Fig. 3a), the InSAR signal is dominated by a large circular pattern related to the 2005-2010 sequence of intrusions along the MH-D segment. This means that the amplitudes of both InSAR and GPS mean velocities must be considered with caution since they result from several transient displacements. Regarding the area of increased mean InSAR velocity extending eastwards towards the Dobi graben and the Mak'Arrassou region, the discrepancy between the two tracks results from the difference of total number of interferograms used for each map, confirming that the amount of deformation and/or residual tropospheric content varies within the 

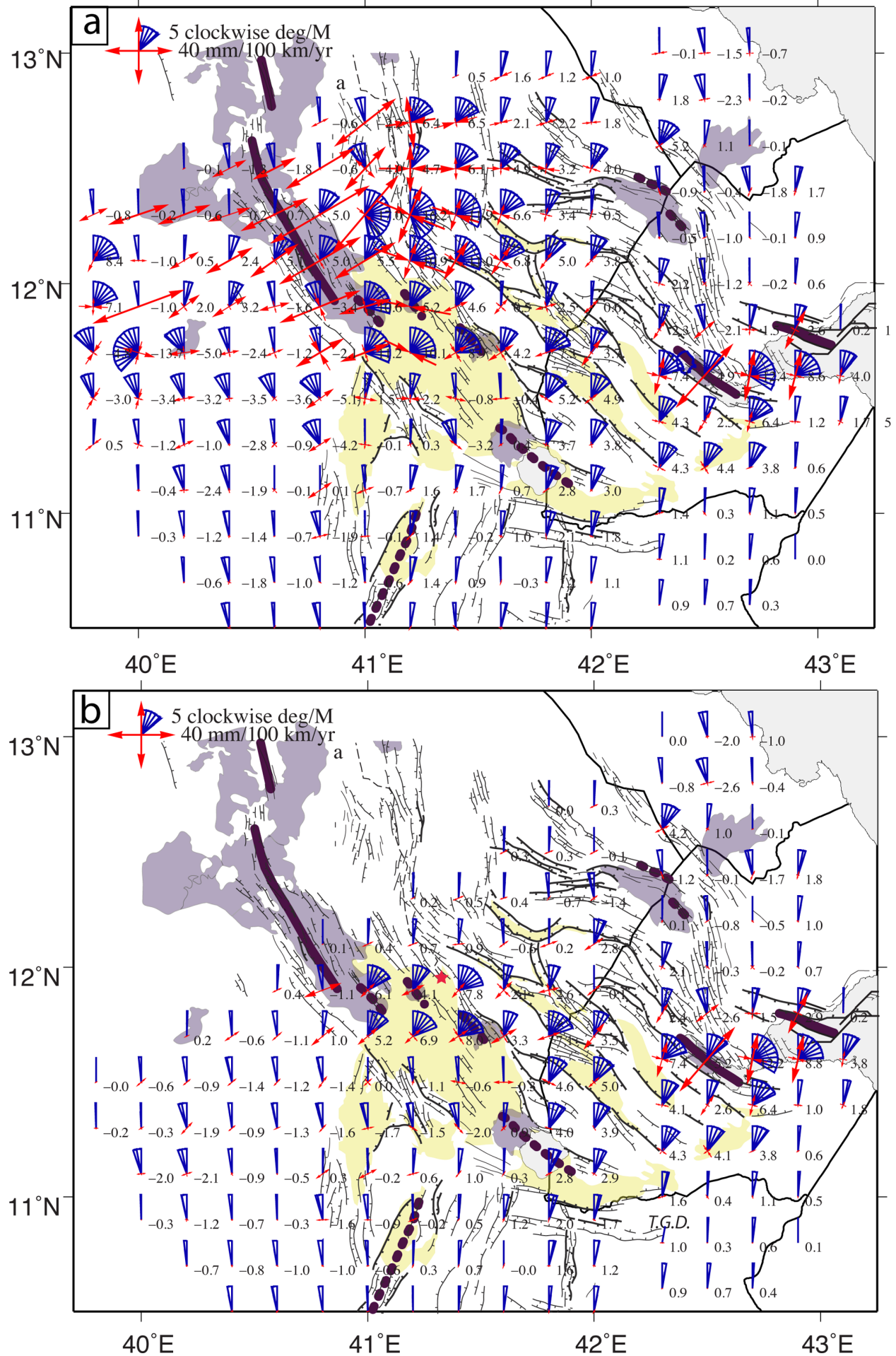

Figure 6. Strain rate tensor and rotation rates in Central Afar (a) with all velocities taken into account (b) without considering transient velocities related to the co- and post-dyking deformation across the MH rift segment (see Figs 4 and 5). The red star in (b) corresponds to the location of the 1969 Serdo Earthquake (Kebede et al. 1989).

interferograms. The strongest gradients in both GPS and InSAR velocity fields (Figs 3 and 4) occur across the Asal-Ghoubbet Rift segment, activated in November 1978 (Abdallah et al. 1979), which thus accommodates a large part of the divergent Arabia/Somalia motion

A major result of the inversion of the strain rate tensor (Fig. 6) is that the direction of the axis of the smallest principal component of the tensor remains perpendicular to most of the tectonic structures visible in the topography, that is scarps of normal faults, over the whole region. This is particularly true for the 1-Myr-old magmatic rift segments (AG, MH-D and Tadjoura), in the amagmatic Dobi Graben, at the border of the TG, but also for the horsts and grabens within the complex zones of extension transfer between the spreading branches. Therefore, the current deformation deduced from the 
GPS data over the 1999-2014 period is consistent with the tectonic forces responsible for the long-term deformation. At small scale, the InSAR maps (Fig. 3) allow us to localize small velocity gradients and patches of signal as indicators of localized surface deformation (such as on the northwestern bank of Lake Abhe) and shallow slips on faults (such as along several large scarps of the Dobi region). However, these latter features must be examined carefully since these gradients also follow elevation steps and a residual stratified atmospheric signal may exist.

\subsection{The northern part of the Main Ethiopian Rift}

This measured GPS network provides more information on the kinematics at the junction of the MER to the AD. Along the northern section of the MER (from latitude $10.5^{\circ} \mathrm{N}$ to $11^{\circ} \mathrm{N}$ ), few measurements are available due to the difficult field accessibility, which prevents detailed GPS constraints on the horizontal velocity field, and particularly across the Adda-do rift segment in southern Afar. Whereas relative horizontal displacements of the margins are not clear in the InSAR data (Figs 3a and c), a slight signal along the along-axis central graben of this rift segment reveals local deformation with a LOS velocity of $\sim 2 \mathrm{~mm} \mathrm{yr}^{-1}$, which could be interpreted as a $2.2 \mathrm{~mm} \mathrm{yr}^{-1}$ subsiding inner-floor. Regarding the GPS data, only the horizontal baseline between the sites of OLAB and BKOB, located $\sim 50$ and $\sim 160 \mathrm{~km}$ away from the rift axis, respectively, can be used to quantify the extension rate. Projected along a $\sim \mathrm{N} 100^{\circ} \mathrm{E}$ trending profile, that is perpendicular to the rift axis, the opening rate is $\sim 3 \mathrm{~mm} \mathrm{yr}^{-1}$, which is lower than the opening rate predicted by the plate motion models at this latitude of the EAR $\left(\sim 5 \mathrm{~mm} \mathrm{yr}^{-1}\right.$ along the $\mathrm{N} 100^{\circ} \mathrm{E}$ direction, Chu \& Gordon 1999; Déprez et al. 2013, 2015; Saria et al. 2014). As shown by Kogan et al. (2012) and Birhanu et al. (2016), the stations located in the southeastern part of the network (BILA, DAMY, ARBK and BKOB) show NE-trending horizontal velocities. That differs from the N090-110 E-trending velocity expected by the present-day plate models (Déprez et al. 2013, 2015; Saria et al. 2013, 2014; Fig. 4). This suggests that a part of the extension due to the motion of the Arabia plate with respect to the Nubia plate is accommodated in southern Afar, in agreement with the $\sim \mathrm{N} 120^{\circ}$ E-trending dyke intrusion deduced from seismic and InSAR data in 2000 at the same latitude (lat: $09.9^{\circ} \mathrm{N}$; Keir et al. 2011). Notably the NE to NNE direction corresponds to the fast shear waves direction in the region, from the latitude $07^{\circ} \mathrm{N}$ (Ayele et al. 2004; Keir et al. 2005; Obrebski et al. 2010).

In the northwestern side of the Adda-do segment, where the strain rate tensor determination is more reliable (Fig. 6b), a slight extension $\left(12 \mathrm{~mm} / 100 \mathrm{~km} \mathrm{yr}^{-1}\right)$ occurs along the SE-NW-trending direction within the Karrayu basin, that Abbate et al. (1995) and Acocella et al. (2008) identified as the western branch of the MER in Afar. Even if no clear activity is in evidence from the morphology of the fault scarps in this area where the erosion is more important than in the other part of the region, a seismic activity is regularly recorded in this basin (Ayele et al. 2015).

\subsection{The Aden propagator}

In eastern Afar, GPS vectors display two distinct sets of velocities: from 3.7 to $7.6 \mathrm{~mm} \mathrm{yr}^{-1}$ along the $\sim \mathrm{N} 070^{\circ} \mathrm{E}$ direction south of the Tadjoura Gulf and the AG rift segment and from 17.9 to $19.9 \mathrm{~mm} \mathrm{yr}^{-1}$ along the $\sim \mathrm{N} 045^{\circ} \mathrm{E}$ direction north (Fig. 4).

This velocity field is consistent with a divergent motion of $\sim 12 \mathrm{~mm} \mathrm{yr}^{-1}$ along the N040 ${ }^{\circ} \mathrm{E}$ direction across the Tadjoura Gulf.
Across the AG rift segment, the opening rate is $\sim 10 \mathrm{~mm} \mathrm{yr}^{-1}$ along the $\sim \mathrm{N} 048^{\circ} \mathrm{E}$ direction, that is $\sim 7 \mathrm{~mm} \mathrm{yr}^{-1}$ less than the opening rate deduced from measurements over the period 1991-2003 by Vigny et al. (2007). East of the AG rift segment, the GPS sites located around the Tadjoura Gulf allow the representation of the distribution of the strain rate tensor on its shores but also within the gulf (Fig. 6). This points out the opening in the area of the Tadjoura rift segment (opening rate of $\sim 25 \mathrm{~mm} / 100 \mathrm{~km} \mathrm{yr}^{-1}$ ), and the strike-slip deformation regime within the transfer zone between the en échelon AG and Tadjoura rift segments (Manighetti et al. 2001). With evidence of the left-lateral slip on these faults, palaeomagnetic measurements give a very high mean clockwise rotation rate of the blocks of $38^{\circ} / \mathrm{Myr}$ over the last $350 \pm 40 \mathrm{kyr}$, which agrees with the rotation rates predicted by the model of bookshelf faulting (Manighetti et al. 2001). The clockwise rotation rates deduced from our geodetic data over the last $15 \mathrm{yr}$ are three times smaller, $12^{\circ}$ Myr. Even if the inversion method used here allows the determination of small-scale variations of the strain rate tensor and rotation rates, the configuration of the network includes very few sites in the eastern part of the Tadjoura Gulf, inducing a resultant distributed extension between the two margins of the Tadjoura Gulf. However, an opening concentrated between the two shoulders of the Tadjoura rift segment would increase the rotation value within the overlap area.

West of the AG rift segment, the velocity field is more complex. The direction of the axis of the smallest principal component of the strain rate tensor from the Tadjoura Gulf to the TG confirms the complexity of the deformation associated with the inland penetration of the divergent AR plate boundary west of longitude $042.5^{\circ} \mathrm{E}$ and suggests that a large part of the extension is located west of the AG segment and not towards the Manda Inakir segment, as proposed by long-term models (Manighetti et al. 1998; Acocella et al. 2008). The velocities estimated south of the MI rift segment are significant (18.9 $\mathrm{mm} \mathrm{yr}^{-1}$ for MAN2 and $21.2 \mathrm{~mm} \mathrm{yr}^{-1}$ for SULA) and close to the value of the ASAB site (Danakil block along the Eritrean coast). Therefore, the current extension across the MI rift segment is either absent or very low. As underlined by both the amplitude and the axis orientation of the minimum principal component of the strain rate tensor, the extension from the AG rift segment extends westward over a large area in Central Afar encompassing most of the basins of Eastern Afar located southwest of the AG rift. This area corresponds as well to the location of rotations larger than $3 \% \mathrm{Myr}$, which contrasts with the small rotation rates along the northern margin of the Tadjoura Gulf, in the northern section of the Mak'Arrassou region, and in the wide area between the Dobi graben and the MI rift segment.

Between the MI and AG active rift segments, the Mak'Arrassou transfer zone has been recognized as an oblique transfer zone with tectonic features consistent with the northwestern propagation of the AR (Tapponnier \& Varet 1974; Manighetti et al. 2001), when Le Gall et al. (2011) and Geoffroy et al. (2014) identify this region as a large monoclinal flexure, similar to those observed along the volcanic passive margin. Due to this spatial configuration of the GPS velocity field and in particular the lack of velocity vector northeast of the Mak'Arrassou, the strain rate tensor inversion shows that NEtrending extension occurs at the southern part of the Mak'Arrassou region, with a low counter-clockwise rotation rate $\left(\sim 2.4^{\circ} / \mathrm{Myr}\right)$ in agreement with low palaeomagnetic values (Manighetti et al. 2001). The distributed extension at the northwestern tip of the AG rift is accompanied by a regular seismic activity in the southern region of the Mak'Arrassou region and by the InSAR data which revealed that normal slip on the numerous eastward $\mathrm{N} 150^{\circ} \mathrm{E}$ trending faults 
prevails over strike-slip regime (Peltzer et al. 2007). The lack of opening detected in the MI rift has therefore a strong influence on the current distribution of the deformation in Mak'Arrassou, and the occurrence of a rifting episode in the MI rift would certainly affect the kinematics in the northern part of the Mak'Arrassou transform zone.

\subsection{The Red Sea propagator}

The sites located on both sides of the MH-D rift axis, up to $\sim 80 \mathrm{~km}$ away, are affected by very large velocities, pointing away from the rift axis. These data estimated over the time period of 2007-2014 encompass significant transient displacements related to co- and post-dyking deformation of the sequence of intrusions in the $\mathrm{MH}$ D segment (Wright et al. 2006; Grandin et al. 2009); therefore the velocity amplitudes at sites located up to $70-80 \mathrm{~km}$ from the rift axis do not represent a steady state deformation. The sites located along the western escarpment of the AD (CHIF, EWCA and KOCA), and considered to belong to the Nubia plate, are affected by westward and southwestward velocities ranging from 7.9 to $19.6 \mathrm{~mm} \mathrm{yr}^{-1}$, suggesting a compression between the Afar domain and the stable high plateaus. Further south, although the sites (CHIF, BATI) are located south of the latitude of the intrusions, they show southwestward velocities as well but with smaller amplitudes. On the eastern side of the rift axis, similar large horizontal NW-ward velocities are calculated at the two cGPS stations nearby, SM2 and GAGI (16.7 and $39.6 \mathrm{~mm} \mathrm{yr}^{-1}$, respectively), and the campaign sites, SILS, KM74 and $\mathrm{K} 103$ (40.4, 43.5 and $48.0 \mathrm{~mm} \mathrm{yr}^{-1}$, respectively; Fig. 4). We note that the velocities at the sites located south of the southern tip of intrusions within the southern section of the MH-D rift segment (SM02, SM03, SOR1, SOR2, SOR3 and HARS; Fig. 5a) remain lower than the far-field Arabia/Nubia velocities.

\subsection{The overlap zone in Central Afar}

A large set of data shows the spatial distribution of the horizontal velocities in Central Afar, recognized as the area enclosed between the overlapping RS and AR propagators (Fig. 1). The amount of extension across the wide TG (from TNDH or HARS to OVLK for instance) does not exceed $2-3 \mathrm{~mm} \mathrm{yr}^{-1}$ with a similar opening across its southeastern and northwestern parts. The strain rate tensor determination shows that the axis of the smallest principal component is perpendicular to the structures in the northwestern half of the TG in the continuation of the MH-D rift segment. In the southeastern half, this axis rotates and becomes E-W, perpendicular to the main fault of Afambo bounding the TG north and northeast of Lake Abhe (north of the site AFBO). The network configuration gives access to the spatial evolution of the rotations, which reach $7.7^{\circ} / \mathrm{Myr}$ in the NW half of the TG, when they almost disappear $\left(<0.5^{\circ} / \mathrm{Myr}\right)$ in the southeastern half. Going east, the $800 \mathrm{~m}$ high scarp of the Afambo fault marks a clear boundary with the large rotation rates in the $\mathrm{SW}$ of Djibouti (Fig. 5b), from the longitude of Lake Abhe to the Hol-Hol lineament (Fig. 1).

Due to accessibility limitations, installing new sites immediately north of the TG was not possible, that is on the southern part of the $\varepsilon$ ounda-Gamarri plateau ( $\varepsilon \mathrm{G}$, Fig. 5 ), which prevented a precise quantification of the deformation accommodated across the Manda Gargori subrift and the large SW-dipping scarp bounding the TG. However the velocities at sites located further north, in the southern shoulder of the Dobi graben (OTTO, OVLK and GELE), show between 3 and $5 \mathrm{~mm} \mathrm{yr}^{-1}$ of $\mathrm{N} 040^{\circ}$ E-trending extension between
KURU and the southwestern scarp bounding the Dobi graben. This area corresponds to the location of the largest strain gradient (Figs 5a and 6).

Also, at the location of the largest event $\left(M_{\mathrm{s}}=6.3\right)$ of the seismic Dobi sequence (Jacques et al. 1999, 2011), a regular gradient of the horizontal velocities is observed across the northwestern part of the Dobi graben and the southeastern part of the NW-trending Gumma graben (Fig. 5). The OTTO and OVLK sites, located at the southeastern side of the structure have velocities of 13.0 and $12.4 \mathrm{~mm} \mathrm{yr}^{-1}$, respectively. The velocities at the sites between the Kadda Dobi and Gumma grabens (DOIW and A035) are similar and equal to $13.7 \mathrm{~mm} \mathrm{yr}^{-1}$, while the velocity north of the Gumma graben is $15.7 \mathrm{~mm} \mathrm{yr}^{-1}$. The strain rate tensor within the Dobi area is consistent with the strike-slip regime (Fig. 6). Along the Djibouti/Ethiopia border where the first shock of the 1989 Dobi seismic sequence occurred, the evolution of the horizontal velocities along the NE-direction is quite similar to what is observed further west, but with a higher increase of $\sim 2 \mathrm{~mm} \mathrm{yr}^{-1}$ between GELE and FARA, corresponding to the southeastern tip of the Dobi graben, while only $\sim 0.4 \mathrm{~mm} \mathrm{yr}^{-1}$ occurs between FARA and GARA (ie. Kambourta graben, Fig. 5c). We therefore observe from TG to the North of Dobi a regular gradient along the NW-direction, within a $50-\mathrm{km}$ wide band, corresponding to the zone identified by Manighetti et al. (2001) as the Gammari-Allol tear zone. From this latter region to the MI rift segment, a $5 \mathrm{~mm} \mathrm{yr}^{-1}$ average of extension is accommodated within the Siyyarou plateau and the Allol graben, as suggested by the InSAR data.

\section{DISCUSSION}

\subsection{Current configuration of the triple junction}

Looking at the long-term deformation, the Afar region cannot be understood as a simple meeting point of three plate boundaries. By testing simple block models, we attempt to reproduce the main features of the GPS velocity field. The first objective is to assess whether the velocity field can be explained by a simple RRR triple junction, which separates rigid blocks deforming elastically at their boundaries, or if additional blocks and internal deformation must be introduced. The second objective is to precisely define the current location, and estimate the kinematics of the main boundaries at surface and at depth. In order to define the block boundaries of the models, we superimposed seismic data [from Ayele et al. (2015) and the permanent Djiboutian seismic network of the Geophysical Observatory of Arta (www.oga.dj)], the Quaternary lava flow locations, the topography, the geodetic data, including GPS and InSAR velocity fields, strain and rotation rate fields described above. Far from Central Afar, the plate boundaries are fixed to the known boundaries (see Section 1 and caption Fig. 7).

As a first approach, we build a first-order model encompassing only three plates separated by the latter boundaries, by joining them in the simplest way (Fig. 7a). Since no extension is measured across the MI rift segment, we extend the Somalia/Arabia boundary from the AG rift segment to Central Afar, across the Der'Ela-Gaggade basin to the Hanle basin (Fig. 1). Regarding the southern prolongation of the RS ridge, we extend the boundary from the MH-D rift towards the recent Manda Gargori subrift. Regarding the northern part of the Adda'do segment, we prolong the boundary along the same direction across the $\mathrm{TG}$, despite the lack of structural features and/or seismicity pattern parallel to this direction. A constant locking depth of all the boundaries is fixed to $15 \mathrm{~km}$. This 

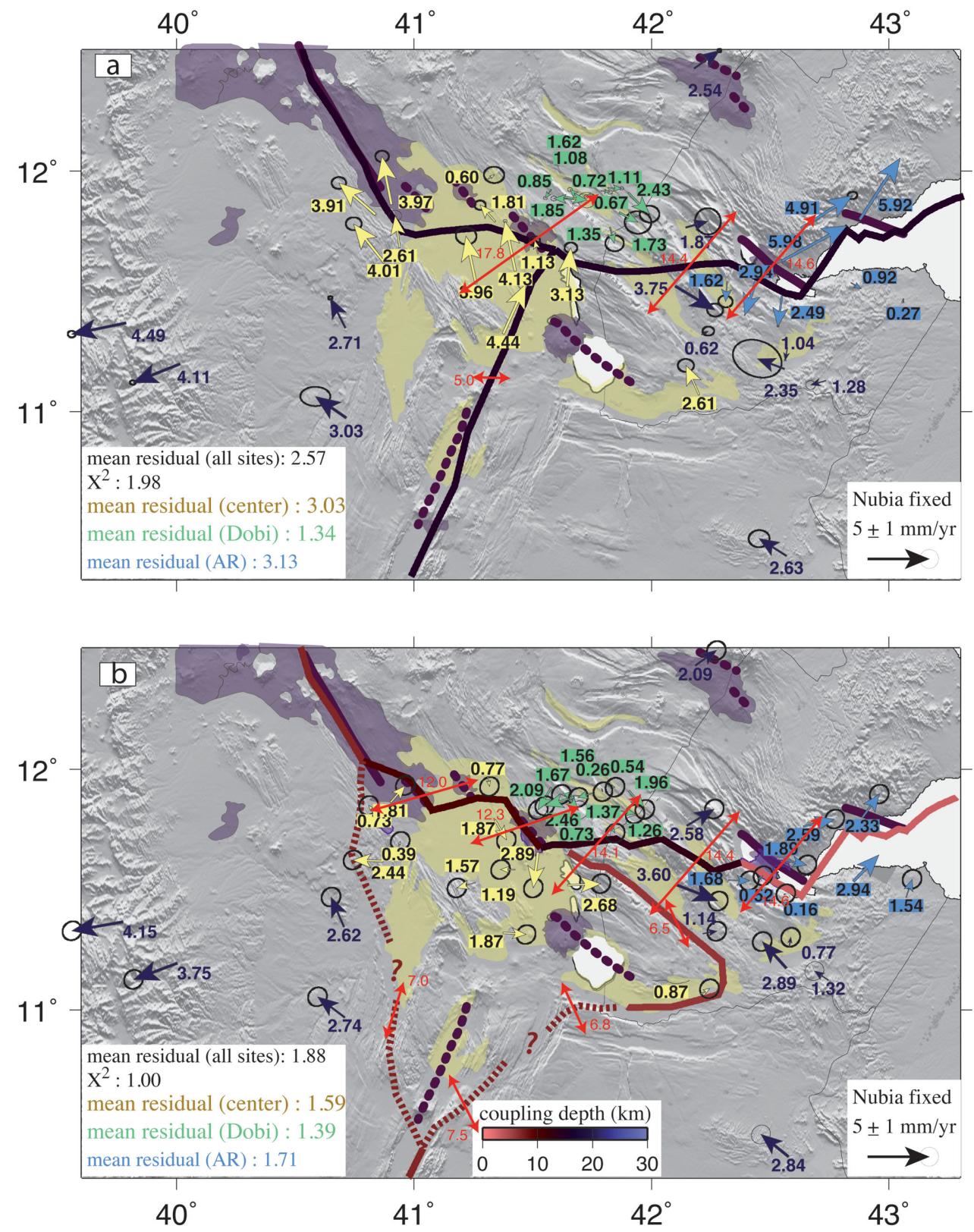

Figure 7. Block models of the Afar triple junction region with three plates (a) and four plates (b). The arrows correspond to the residuals between the modelled and observed velocities. For the model (a) the plate motions are fixed, for the model (b) both the rotation of the central microblock and the coupling depth are inverted. The Red Sea Ridge extends into Central Afar through the MH-D rift segment, clearly defined as south as latitude $12^{\circ} \mathrm{N}$ following the deformation pattern of the last dyking sequence (Fig. 7). The Aden Ridge reaches Central Afar through the Tadjoura Gulf, following the mapping of the structure of Manighetti et al. (1997), and along the AG rift segment. We note that, for clarity, the transfer zone in the overlap between the Tadjoura and AR rift segments is modelled by a NE-trending right-lateral transform zone and not by the rotation of NW-trending elongated blocks. In southern Afar, the divergent plate boundary corresponds to the MER extending to the Adda'do graben (as north as lat $\sim 10.5^{\circ} \mathrm{N}$ ). The red arrows correspond to the direction and amplitude (value indicated) of the relative motion along the block boundary at depth.

first-order model explains the data with a 75 per cent variance reduction and reproduces the observed clockwise rotation of the vectors over Afar described above (Fig. 7a). This model is compatible with a deep opening of $14.6 \mathrm{~mm} \mathrm{yr}^{-1}$ across the AG rift and $5.0 \mathrm{~mm} \mathrm{yr}^{-1}$ across the MER. Regarding the AG rift segment, large residual values ( $>3 \mathrm{~mm} \mathrm{yr}^{-1}$, blue arrows Fig. $7 \mathrm{a}$ ) are visible on both sides suggesting that this segment is not locked down to $15 \mathrm{~km}$. This oversimple model also predicts a deep right lateral trans-tension below the basins in Central Afar $\left(\sim 9.5 \mathrm{~mm} \mathrm{yr}^{-1}\right.$ of deep opening and $10.5 \mathrm{~mm} \mathrm{yr}^{-1}$ of strike-slip motion). However, in the TG and south- west of the MH-D rift segment, we observe a systematic pattern of residuals of $\sim 3 \mathrm{~mm} \mathrm{yr}^{-1}$ towards the north (yellow arrows, Fig $7 \mathrm{a}$ ), suggesting a local complexity that the model does not take into account. We note the slight northeastward increase of the residuals within the Dobi graben and along the Ethiopia/Djibouti border that indicates that a boundary should be located south of this area.

A second model attempts to better fit the GPS velocities by inverting the coupling depth along the boundaries and by adding one central microblock for which the rotation pole is also inverted (Fig. 7b). Both the spatial density of GPS measurements and the 
quality of the InSAR surface velocity maps are still insufficient to constrain the rotation rate and boundaries of the numerous blocks, required by the bookshelf faulting model. Similar to the first-order model, we draw the boundary far from Central Afar, and then, using our geodetic results and geological considerations, the borders of the central microblock. Taking into account both the evidence of extensional strain and the occurrence of seismic swarms in the Karrayu basin (Ayele et al. 2015), we split the southern divergent boundary into the Adda-do rift segment and this basin. This Karrayu basin has been recognized as a Quaternary tectonically active branch of the MER (e.g. Abbate et al. 1995; Acocella et al. 2008) in agreement with the modern Awash River incision (Quade et al. 2008). The northern boundary of the central microblock follows the axis of the Loma and Manda Gargori (MG) subrifts. However, the eastern border appears more complex. Following the results of the first order model, the best fit requires the site east of Lake Abhe (DXD0) to evolve with the central microblock. With no additional microblocks whose kinematics would not be well resolved from the available data, the geometry of the microblock is irregular, such as the right angle at the junction of the Adda'do and Goba'ad-Dama Ale segments. Large perpendicular faults are building the topography in this area with no clear chronological criteria, suggesting that the stress conditions induced by the Arabia/Somalia or the Nubia/Somalia divergent motion are more or less equivalent. This block geometry cannot remain stable over the long-term, particularly regarding the two narrow « lumps », between the Karrayu basin and the Adda'do rift segment, and between Lake Abhe and the Hanle basin. As the complex geometry of the central microblock appears necessary to model the current deformation field (residual velocities $\approx$ uncertainties of measured GPS velocities), the snapshot of the deformation at a specific time given by this data set, shows that the long-term deformation implies a succession of deformation patterns over time which are certainly dependent on both the locations of the active rift segments and their respective evolution stage within the rifting cycle. As discussed below, the behaviour of the divergent plate boundary highly depends on the magma supply, which also modifies the elastic thickness (e.g. Grandin et al. 2012). This four-block model reduces by 82 per cent the variance of the measured velocity field. We applied the $F$-ratio test adapted by Stein \& Gordon (1984) in order to estimate the improvement in the fit of this four-block model relative to the previous model, that is to test if the reduction of variance effectively confirms an improvement of the model or simply results from the addition of three degrees of freedom (angular velocity of the central block). By inverting the 42 velocity vectors, we obtain a $F$ value of 10.38 (with $v_{1}=3$, and $v_{2}=33$ ), that is greater than the value of $F_{0.01}=7.0$ or $F_{0.05}=3.8$, supporting the existence of the central block. The inverted coupling depth along the mature AG rift segment is very low $(3 \mathrm{~km}$, i.e. same order of the value of the elastic thickness deduced from co-dyking geodetic inversions and seismic data (Tarantola et al. 1979, 1980; Doubre et al. 2007; Smittarello et al. 2016). On the contrary, along the northern boundary of the microblock, the inverted coupling depth is significantly higher $(10-13 \mathrm{~km})$. This approach demonstrates that the current deformation in Afar can be described as a complex triple junction including a wide central zone, modelled as an independent block. The measured ground deformation can be explained by a simple model with the deformation being localized on a few interseismically locked dislocations. The required geometry for the plate boundaries implies that the Arabia-Africa motion is currently accommodated at depth mainly by an EW-trending zone of trans-tensive shear at depth $\left(13 \mathrm{~mm} \mathrm{yr}^{-1}\right.$ of opening and $4 \mathrm{~mm} \mathrm{yr}^{-1}$ of lateral slip), that may be released in future seismic or dyking crises affecting the en échelon $\sim \mathrm{N} 150^{\circ}$ E-trending amagmatic grabens and/or magmato-tectocic rift segments visible at the surface across Central Afar. Between these basins and rift segments the transfer of deformation does not involve right-lateral strike-slip faults, but most likely block rotations following the mechanism of bookshelf faulting as observed between AG and Tadjoura segments (Manighetti et al. 1998, 2001).

\subsection{Transitory spreading ridges}

Regarding the known spreading axes, the velocity fields presented in this study show that (1) the largest opening occurs across the recently activated rift segments and (2) very low deformation or not at all occurs elsewhere, in particular across other rift segments identified to be as likewise active over the Quaternary (Figs 4 and 6). Among the latter one, the Adda'do rift segment, considered as a continental segment, exhibits eroded fault scarps and almost no fresh basalt flows, which indicates recent rifting episodes. To the north, the onset of rifting in the MI rift segment is estimated to $\sim 190-140 \mathrm{kyr}$ and the last seismo-volcanic event was in 1929 (Civetta et al. 1975; Gouin 1979; Audin et al. 1990; Vellutini 1990; Manighetti et al. 1998), with a rifting recurrence time of $670 \mathrm{yr}$. The low opening across the rift $\left(0.7 \mathrm{~mm} \mathrm{yr}^{-1}\right)$ strongly suggests that the mechanical response of the rifting episode is over, and that this rift segment is currently " sealed ». This result is consistent with chemical analyses of the lavas showing that the magma source is deeper and less evolved than in the AG rift segment (Audin et al. 1990) and that the plate boundary remains less developed at depth than in older sections of the AR (AG, Tadjoura).

Regarding the Tendaho Graben (TG), even if the lavas are fresh in the Manda Gargori, no volcanic eruption has been reported in historical time. The K/Ar and thermoluminescence dating by Lahitte et al. (2003) give some estimates of 90 and $220 \mathrm{ka}$ for the lava flows, but they notice that the aspect of the lavas on the field suggests more recent volcanic activity. We have observed some smoking and venting of high temperatures during the last GPS campaign in 2014 in this area. Unlike Acocella et al. (2008) who consider that the whole TG is a fading rift and that the extension occurs mainly in the MI since 0.2 Ma, Manighetti et al. (1998) identify the MG subrift as the main active area in the TG, active from the last $0.2 \mathrm{Ma}$ coeval with the MI rift segment onset. The present-day opening velocity across the MG subrift is $5 \mathrm{~mm} \mathrm{yr}^{-1}$ and associated with $\sim 2.0 \mathrm{~mm} \mathrm{yr}^{-1}$ of vertical motion along its northern border, as revealed by InSAR data.

This discrepancy between the Plio-Pleistocene deformation and present-day deformation once again illustrates that the geodetic data capture a snapshot of the surface deformation in a specific period during which no large displacements occur at the tips of the three divergent plate boundaries tearing the crust in Afar. The studies on the evolution of the rift segments over the last three decades in Afar, but also in Iceland, and along mid-oceanic ridges, clearly show that these large displacements are transient and are primarily related to magma intrusion(s). The small opening across the MI, the subrifts in the TG, and the Adda'do segments during the interdyking period is probably due to the unavailability of magma. This also suggests that the tips of the divergent plate boundaries may not have been mature enough to remain the site of velocity gradients due to either a negligible local thinning of the brittle layer, or to a poor magma supply that weakens the lithosphere locally. The magmato-tectonic evolution of rift segments is classically viewed as a short-term alternating of magmatic dilatation associated with surface rupture 
(fissures and slips on normal faults) during the co-dyking periods, and mainly tectonic activity during interdyking periods (Rubin 1990). Considering these results, the current morphology of the rift segments mainly results from magmatic rifting episodes and hardly from the tectonic activity over the rest of the rifting cycle.

\subsection{Localized versus distributed deformation}

Within the snapshot of the deformation revealed by our data, two kinds of deformation occur in Afar: a localized deformation associated with high transient displacements in the active magmatotectonic rift segments, and a steady-state extension distributed over a NW-trending 70-km-wide band in Central Afar that may be regarded as the last region of attachment between the Arabia and Africa plates characterized by a thicker elastic layer. However, despite the series of horsts and grabens bounded by numerous large and small normal faults, the amount of tectonic extension appears to be limited, since the tilting of blocks is generally very low $\left(<1^{\circ}\right.$; Jacques et al. 2011), not exceeding $17^{\circ}$ in a few cases (Souriot \& Brun 1992). According to the smooth gradient in the velocity field, most of the deformation appears to correspond to elastic extension throughout Central Afar with few structures in surface accommodating the far field motion. The distribution of deformation at a large scale over Afar recalls the Oligo-Miocene for the evolution of the extension over Afar by Stab et al. (2016). Unlike Wolfenden et al. (2005) who draw the evolution of the locus of extension as a migration of focused extension toward the current active axes, Stab et al. (2016) show that the focusing of the extension in Afar is very recent and coeval with the emplacement of large magmatic centres corresponding to the Quaternary segments $(\sim 1.1 \mathrm{Ma}$, Kidane et al. 2003; Lahitte et al. 2003). If the magma supply is insufficient within the magmato-tectocic segments, and especially those at the tip of the spreading axes (MI and MG), the extensive deviatoric stresses can potentially be released during tectonic events through the slip on numerous and intricate faults, such as the 1989 sequence Dobi (Sigmundsson 1992; Jacques et al. 1999, 2011).

\section{CONCLUSIONS}

The combination of the two spatial geodetic methods, GPS and InSAR, is an appropriate way to specifically study the crustal deformation in Central Afar. In addition of the geometric complementarity of the measurements, the GPS technique allows the quantification of the relative plate motion while the InSAR technique gives access to deformation across small-scale structures. However, while InSAR showed its potential for studying large amplitude displacements in Afar, such as the dyke sequence along the MH-D rift segment (Wright et al. 2006; Grandin et al. 2009; Hamling et al. 2009), the measurement of small amplitude displacement is complex due to the turbulent tropospheric signal, except in the case of very large SAR image data set, such as the 11-yr-long archive of Radarsat-1 images acquired every $24 \mathrm{~d}$. The InSAR time-series allows Doubre \& Peltzer (2007) to measure slip rates along normal faults with an order of magnitude lower than $1 \mathrm{~mm} \mathrm{yr}^{-1}$. Until the treatment of the SAR images from the new satellite Sentinel-1, acquired every $12 \mathrm{~d}$, which will provide important constraints on the surface velocity map, GPS presently appears to be the more appropriate technique to accurately quantify the low surface strain in Afar, and required a dense network of measurement sites in order to satisfactorily describe both distributed and localized deformation.
At large scale, the GPS velocities are consistent with the far field plate motion deduced from tectonic models, except for the northern part of the Somalia plate, where the vectors show a NE trending motion from low latitudes, in agreement with the observations of Kogan et al. (2012) and Birhanu et al. (2016) that were made across the Central MER. This suggests that the northern part of the Somalia plate evolves independently from the whole Somalia plate, whose motion is determined from GPS stations mainly located in the Southern Hemisphere.

At regional scale, the largest velocity gradients occur across the two magmato-tectonic segments which have been activated over the last decades, and the large opening rate corresponds to the deformation following a significant amount of extension due to magma intrusions several metres wide: the MH-D rift segment activated in 2005-2010 and the AG rift segment activated in 1978. On the contrary, little deformation is observed across the other Quaternary active rift segments. This suggests that the transient behaviour of the segments dominates the long-term deformation at the divergent plate boundary. Except for these two segments, the GPS horizontal velocity field reveals a wide zone of distributed deformation, with a regular gradient from the SW to the NE and more specifically a clockwise rotation of the velocity field from SW to East. Similarly, the InSAR velocity field, mainly consistent with vertical displacements, does not allow the identification of clear shallow creeping structures. However, simple block models indicate that the triple junction kinematics involves an independent block in Central Afar. These models show that the surface deformation is consistent with a deep trans-tensional $\sim$ EW-trending boundary connecting these two latter volcano-tectonic rift segments. This boundary, locked for the 10-13 first kilometres of the crust, consists on surface of a series of en échelon $\sim \mathrm{N} 150^{\circ}$ E-trending grabens and magmato-tectonic subrifts.

By comparing the topography in Central Afar with our results, a significant outcome is that the short-term deformation field is consistent with a large part of the long-term deformation over the southern part of Central Afar, since the extensional axis of the deformation tensor remains perpendicular to the large normal faults bounding the series of horsts, grabens and subrifts dissecting the topographic surface. This consistency suggests that the current configuration of the active plate boundary must have prevailed over the last 2-4 Ma (age of the Stratoid series).

\section{ACKNOWLEDGEMENTS}

This work was supported by the Agence Nationale pour la Recherche, in the framework of the project DoRA ANR-09-JCJC0051-01, and partly by CNES-TOSCA. We thank all the participants of the measurement campaigns, and teams involved to make the data available. The data were acquired using the instruments belonging to the French National Research Infrastructure RESIF (http://www.resif.fr), supported by the Ministry of Research and Higher Education and through the 'Investissements d'avenir' (ANR-11-EQPX-0040). We are grateful to our colleagues from the Institute of Geophysics, Space Sciences and Astronomy from Addis Ababa University, and from the Centre d'Etudes et de Recherches Djiboutiennes (Dir. Mohamed Jalludin), and the Observatoire Géophysique d'Arta (www.oga.dj). Support from the authorities of the Afar regional government in Semera has been crucial and they are warmly thanked, as well as the policemen who accompanied us in the field. The fieldwork has been made possible with the logistic support of the Centre Français d'Etudes Ethiopiennes in 
Addis-Ababa, and from Eloi Ficquet and David Ambrosetti in particular. Special thanks are addressed to the Ethiopian and Djiboutian drivers (Semeneh Bacha, Amare Setotaw, Temechache Yirfu, Wegen Amerga and Mohamed Amadou), and to Yves Bertrand and Bernard Luck for their precious help in the field.

\section{REFERENCES}

Abbate, E., Passerini, P. \& Zan, L., 1995. Strike-slip faults in a rift area: a transect in the Afar Triangle, East Africa, Tectonophysics, 241, 67-97.

Abdallah, A. et al., 1979. Relevance of Afar seismicity and volcanism to the mechanics of accreting plate boundaries, Nature, 282, 17-23.

Acocella, V., Abebe, B., Korme, T. \& Barberi, F., 2008. Structure of Tendaho Graben and Manda Hararo Rift: implications for the evolution of the southern Red Sea propagator in Central Afar, Tectonics, 27, doi:10.1029/2007TC002236

Acton, G.D., Stein, S. \& Engeln, J., 1991. Block rotation and continental extension in Afar: a comparison to oceanic microplate systems, Tectonics, 10, 501-526.

Acton, G.D., Tessema, A., Jackson, M. \& Bilham, R., 2000. The tectonic and geomagnetic significance of paleomagnetic observations from volcanic rocks from central Afar, Africa, Earth planet. Sci. Lett., 180, 225-241.

Altamini, Z., Métivier, L. \& Collilieux, X., 2008. ITRF2008 plate motion model, J. geophys. Res., 117, B07402, doi:10.101029/2011JB008930.

ArRajehi, A. et al., 2009. Geodetic constraints on present-day motion of the Arabian Plate: implications for Red Sea and Gulf of Aden rifting, Tectonics, 29, doi:10.1029/2009TC002482.

Audin, J., Vellutini, P., Coulon, C., Piguet, P. \& Vincent, J., 1990. The 19281929 eruption of Kammourta volcano-evidence of tectono-magmatic activity in the Manda-Inakir rift and comparison with the Asal Rift, Afar Depression, Republic of Djibuti, Bull. Volc., 52, 551-561.

Audin, L. et al., 2004. Paleomagnetism and K-Ar and 40Ar/39Ar ages in the Ali Sabieh area (Republic of Djibouti and Ethiopia): constraints on the mechanism of Aden ridge propagation into southeastern Afar during the last $10 \mathrm{Myr}$ (2004, Geophys. J. Int., 158, 327-345.

Ayele, A., Stuart, G. \& Kendall, J.-M., 2004. Insights into rifting from shear wave splitting and receiver functions: an example from Ethiopia, Geophys. J. Int., 157, 354-362.

Ayele, A., Stuart, G., Bastow, I. \& Keir, D., 2007a. The August 2002 earthquake sequence in north Afar: insights into the neotectonics of the Danakil microplate, J. Afric. Earth Sci., 48, 70-79.

Ayele, A. et al., 2007b. The volcano-seismic crisis in Afar, Ethiopia, starting September 2005, Earth. planet. Sci. Lett., 255, 177-187.

Ayele, A., Ebinger, C., Van Alstyne, C., Keir, D., Nixon, C., Belachew, M. \& Hammond, J., 2015. Seismicity of the central Afar rift and implications for Tendaho dam hazards, in Magmatic Rifting and Active Volcanism, eds Wright, T.J., Ayele, A., Ferguson, D.J., Kidane, T. \& Vye-Brown, C. Geol. Soc., Spec. Publ., vol. 420, pp. 341-354.

Barberi, F. \& Varet, J., 1970. The Erta Ale volcanic range (Danakil depression, northern Afar, Ethiopia), Bull. Volc., 36, 848-917.

Barberi, F. \& Varet, J., 1972. Carte volcanologique et pétrologique de la chaine de l'Erta'Ale (Afar, Ethiopie) au 1/100.000, Géotechnip.

Barberi, F. \& Varet, J., 1977. Volcanism of Afar: small-scale plate tectonics implications, Geol. Soc. Am. Bull., 88, 1251-1266.

Beauducel, F., Briole, P. \& Froger, J.-L., 2000. Volcano-wide fringes in ERS synthetic aperture radar interferograms of Etna (1992-1998): deformation or tropospheric effect?, J. geophys. Res., 105, 16 391-16 402.

Belachew, M., Ebinger, C., Coté, D., Keir, D., Rowland, J.V., Hammond, J.O.S. \& Ayele, A., 2011. Comparison of dyke intrusions in an incipient seafloor-spreading segment in Afar, Ethiopia: seismicity perspectives, $J$. geophys. Res., 116, doi:10.1029/2010JB007908.

Birhanu, Y., Bendick, R., Fisseha, S., Lewi, E., Floyd, M., King, R. \& Reilinger, R., 2016. GPS constraints on broad scale extension in the Ethiopian Highlands and Main Ethiopian Rift, Geophys. Res. Lett., 43, doi:10.1002/2016GL069890.

Calais, E., 2008. Afar 2008, UNAVCO, GPS Data Set, doi:10.7283/ T5PV6HFZ.
Calais, E., 2009. Afar 2009: October, UNAVCO, GPS Data Set, doi:10.7283/ T5TH8JSD

Calais, E. \& Buck, R., 2007. Afar 2007: March, UNAVCO, GPS Data Set, doi:10.7283/T51Z42HV

Chu, D. \& Gordon, R., 1999. Evidence for motion between Nubia and Somalia along the Southwest India ridge, Nature, 398, 64-67.

Civetta, L., De Fino, M., Gasparini, P., Ghiara, M., La Volpe, L. \& Lirer, L., 1975. Structural meaning of East-Central Afar volcanism (Ethiopia, T.F.A.I.), J. Volc., 83, 363-373.

Courtillot, V., Achache, J., Landre, F., Bonhommet, N., Montigny, R. \& Féraud, G., 1984. Episodic spreading and rift propagation: new paleomagnetic and geochronologic data from the Afar nascent passive margin, J. geophys. Res., 89, 3315-3333.

Courtillot, V., Armijo, R. \& Tapponnier, P., 1987. The Sinai triple junction revisited, Tectonophysics, 141, 181-190.

Courtillot, V., Jaupart, C., Manighetti, I., Tapponnier, P. \& Besse, J., 1999. On causal links between flood basalts and continental breakup, Earth planet. Sci. Lett., 166, 177-195.

Déprez, A., Doubre, C., Masson, F. \& Ulrich, P., 2013. Seismic and aseismic deformation along the East African Rift System from a reanalysis of the GPS velocity field of Africa, Geophys. J. Int., 193, 1353-1369.

Déprez, A., Doubre, C., Masson, F. \& Ulrich, P., 2015. Erratum: Seismic and aseismic deformation along the East African Rift System from a reanalysis of the GPS velocity field of Africa, Geophys. J. Int., 200, 556.

Doin, M.-P., Lasserre, C., Peltzer, G., Cavalié, O. \& Doubre, C., 2009. Corrections of stratified tropospheric delays in SAR interferometry: validation with global atmospheric models, J. appl. Geophys., 69, $35-50$.

Doin, M.-P. et al., 2011. Presentation of the small baseline NSBAS processing chain on a case example: the Etna deformation monitoring from 2003 to 2010 using Envisat data, in Proceedings of the Fringe Symposium, Frascati, Italy, ESA SP-697.

Doubre, C. \& Peltzer, G., 2007. Fluid-controlled faulting process in the Asal Rift, Djibouti, from 8 yr of radar interferometry observations, Geology, 35, 69-72.

Doubre, C., Manighetti, I., Dorbath, L., Dorbath, C., Bertil, D. \& Delmond, J.-C., 2007. Crustal structure and magmato-tectonic processes in an active rift (Asal-Ghoubbet, Afar, East Africa): 2. Insights from the 23-year recording of seismicity since the last rifting event, J. geophys. Res., 112, B05406, doi:10.1029/2006JB004333.

Doubre, C. et al., 2014. Large geodetic time series constraining the spatial distribution and the time evolution of the velocity field at the western tip of the Aden Ridge in Afar, Abstract G11B-0497 presented at 2014 Fall Meeting, AGU, San Francisco, California, 15-19 December.

Ducret, G., Doin, M.-P., Grandin, R. \& Lasserre, C., 2013. DEM corrections before unwrapping in a small baseline strategy for inSAR time series analysis, Geosci. Remote Sens. Lett., 11, 696-700.

Eagles, G., Gloaguen, R. \& Ebinger, C., 2002. Kinematics of the Danakil microplate, Earth planet. Sci. Lett., 203, 607-620.

Ebinger, C.J. \& Sleep, N.H., 1998. Cenozoic magmatism throughout east Africa resulting from impact of a single plume, Lett. Nature, 395, 788791.

Ebinger, C. et al., 2008. Capturing magma intrusion and faulting processes during continental rupture: seismicity of the Dabbahu (Afar) rift, Geophys. J. Int., 174, 1138-1152.

Geoffroy, L., Le Gall, B., Daoud, M. \& Jalludin, M., 2014. Flip-flop detachment tectonics at nascent passive margins in SE Afar, J. Geol. Soc., 171, 689-694.

Gouin, P., 1979. Earthquake History of Ethiopia and the Horn of Africa, International Development Research Centre, $258 \mathrm{pp}$.

Grandin, R., Socquet, A., Binet, R., Klinger, Y., Jacques, E., de Chabalier, J.-B. \& Pinzuti, P., 2009. September 2005 Manda Hararo-Dabbahu rifting event, Afar (Ethiopia): constraints provided by geodetic data, J. geophys. Res., 114, doi:10.1029/2008JB005843.

Grandin, R. et al., 2011. Seismicity during lateral dyke propagation: insights from new data in the recent Manda Hararo-Dabbahu rifting episode (Afar, Ethiopia), Geochem. Geophys. Geosyst., 12, Q0AB08, doi:10.1029/2010GC003434. 
Grandin, R., Socquet, A., Doubre, C., Jacques, E. \& King, G.C.P., 2012. Elastic thickness control of lateral dyke intrusion at mid-ocean ridges, Earth Planet. Sci. Lett., 319-320, 83-95.

Hamling, I. et al., 2009. Geodetic observations on the ongoing Dabbahu rifting episode: new dyke intrusions in 2006 and 2006, Geophys. J. Int., 178, 989-1003.

Hamling, I., Wright, T., Calais, E., Lewi, E. \& Fukahata, Y., 2014. InSAR observations of post-rifting deformation around the Dabbahu rift segment, Afar, Ethiopia, Geophys. J. Int., 197, 33-49.

Hammond, J. et al., 2013. Mantle upwelling and initiation of rift segmentation beneath the Afar Depression, Geology, 41, 635-638.

Hayward, N.J. \& Ebinger, C.J., 1996. Variations in the along-axis segmentation of the Afar Rift system, Tectonics, 15, 244-257.

Hofmann, C., Courtillot, V., Féraud, G., Rochette, P., Yirgu, G., Ketefo, E. \& Pik, R., 1997. Timing of the Ethiopian flood basalt event and implications for the plume birth and global change, Nature, 389, 838-841.

Hofstetter, R. \& Beyth, M., 2003. The Afar Depression: interpretation of the 1960-2000 earthquakes, Geophys. J. Int., 155, 715-732.

Hooper, A., Segall, P. \& Zebker, H., 2007. Persistent scatterer interferometric synthetic aperture radar for crustal deformation analysis, with application to Volcán Alcedo, Galápagos, J. geophys. Res., 112, B07407, doi: 10.1029/2006JB004763.

Jacques, E., Ruegg, J.-C., Lépine, J.-C, Tapponnier, P., King, G. \& Omar, A., 1999. Relocation of $M \geq 2$ events of the 1989 Dôbi seismic sequence in Afar: evidence for earthquake migration, Geophys. J. Int., 138, 447-469.

Jacques, E. et al., 2011. Normal faulting during the August 1989 earthquakes in Central Afar: sequential triggering and propagation of rupture along the Dôbi Graben, Bull. Seism. Soc. Amer., 101, 994-1023.

Jestin, F., Huchon, P. \& Gaulier, J.-M., 1994. The Somalia plate and the East African Rift System: present-day kinematics, Geophys. J. Int., 116, 637-654.

Jolivet, R., Grandin, R., Lasserre, C., Doin, M.-P. \& Peltzer, G., 2011. Systematic InSAR tropospheric phase delay corrections from global meteorological reanalysis data, Geophys. Res. Lett., 38, L17311, doi:10.1029/2011GL048757.

Kebede, F., Kim, W. \& Kulhanek, O., 1989. Dynamic source parameters of the March-May 1969 Serdo Earthquake sequence in central Afar, Ethiopia, deduced from teleseismic body waves, J. geophys. Res., 94, 5603-5614.

Keir, D., Kendall, J-M., Ebinger, C.J. \& Stuart, G.W., 2005. Variations in late syn-rift melt alignment inferred from shear-wave splitting in crustal earthquakes beneath the Ethiopian rift, Geophys. Res. Lett., 32, L23308, doi: 10.1029/2005GL024150.

Keir, D. et al., 2009a. Evidence for focused magmatic accretion at segment centers from lateral dyke injections captured beneath the Red Sea rift in Afar, Geology, 37, 59-62.

Keir, D., Bastow, I., Whaler, K., Daly, E., Cornwell, D. \& Hautot, S., 2009b. Lower crustal earthquakes near the Ethiopian rift induced by magmatic processes, Geochem. Geophys. Geosyst., 10, doi:10.1029/2009GC002382.

Keir, D., Pagli, C., Bastow, I.D. \& Ayele, A., 2011. The magmaassisted removal of Arabia in Afar: evidence from dyke injection in the Ethiopian rift captured using InSAR and seismicity, Tectonics, 30, doi: 10.1029/2010TC002785.

Kidane, T. et al., 2003. New paleomagnetic and geochronologic results from Ethiopian Afar: block rotations linked to rift overlap and propagation and determination of a $\sim 2$ Ma reference pole for stable Africa, J. geophys. Res., 108, doi:10.1029/2001JB000645.

King, R.W. \& Bock, Y., 2010. Documentation for the GAMIT/GLOBK GPS software analysis, release 10.05, Massachusetts Institute of Technology, Cambridge.

Kogan, L., Fisseha, S., Bendick, R., Reilinger, R., McClusky, S., King, R. \& Solomon, T., 2012. Lithospheric strength and strain localization in continental extension from observations of the east African Rift, $J$. geophys. Res., 117, doi:10.1029/2011JB008516.

Korostelev, F. et al. 2015. Magmatism on rift flanks: insights from ambient noise phase velocity in Afar region, Geophys. Res. Lett., 42, 2179-2188.
Lahitte, P., Gillot, P.-Y., Kidane, T., Courtillot, V. \& Bekele, A., 2003. New age constraints on the timing of volcanism in central Afar, in the presence of propagating rifts, J. geophys. Res., 108, 2123, doi:10.1029/2001JB001689.

Le Gall, B., Daoud, M., Rolet, J. \& Egueh, N., 2011. Large-scale flexuring and antithetic extensional faulting along a nascent plate boundary in the SE Afar rift, Terra Nova, 23 416-420.

Manighetti, I., Tapponnier, P., Courtillot, V., Gruszow, S. \& Gillot, P.-Y., 1997. Propagation of rifting along the Arabia-Somalia plate boundary: the gulfs of Aden and Tadjoura, J. geophys. Res., 102, 2681-2710.

Manighetti, I., Tapponnier, P., Gillot, P.-Y., Jacques, E., Courtillot, V., Armijo, R. \& King, G., 1998. Propagation of rifting along the ArabiaSomalia plate boundary: Into Afar, J. geophys. Res., 103, 4947-4974.

Manighetti, I., Tapponnier, P., Courtillot, V., Gallet, Y., Jacques, E. \& Gillot, P.-Y., 2001. Strain transfer between disconnected, propagating rifts in Afar, J. geophys. Res., 106, 13 613-13 665.

Masson, F., Lehujeur, M., Ziegler, Y. \& Doubre, C., 2014. Strain rate tensor in Iran from a new GPS velocity field, Geophys. J. Int., 197, 10-21.

McCaffrey, R., 1995. DEFNODE Users' Guide, Rensselaer Polytech. Inst.

McCaffrey, R., 2002. Crustal block rotations and plate coupling, in Plate Boundary Zones, eds Stein, S. \& Freymueller, J., Vol. 30, pp. 101-122, AGU Geodynamics Series.

McCaffrey, R., 2009. Time-dependent inversion of three-component continuous GPS for steady and transient sources in northern Cascadia, Geophys. Res. Lett., 36, doi:10.1029/2008GL036784.

McClusky, S., Reilinger, R., Ogubazghi, G., Amleson, A., Healeb, B., Vernant, P. \& Kogan, L., 2010. Kinematics of the southern Red Sea-Afar Triple Junction and implications for plate dynamics, Geophys. Res. Lett., 37, doi:10.1029/2009GL041127.

Noir, J., Jacques, E., Békri, S., Adler, P., Tapponnier, P. \& King, G.C.P., 1997. Fluid flow triggered migration of events in the 1989 Dobi Earthquake sequence of central Afar, Geophys. Res. Lett., 24, 2335-2338.

Nooner, S.L., Bennati, L., Calais, E., Buck, W.R., Hamling, I.J., Wright, T.J. \& Lewi, E., 2009. Post-rifting relaxation in the Afar region, Ethiopia, Geophys. Res. Lett., 36, L21308, doi:10.1029/2009GL040502.

Obrebski, M., Kiselev, S., Vinnik, L. \& Montagner, J., 2010. Anisotropic stratification beneath Africa from joint inversion of SKS and P receiver functions, J. geophys. Res., 115, doi:10.1029/2009JB006923.

Pagli, C., Wang, H., Wright, T.J., Calais, E. \& Lewi, E., 2014. Current plate boundary deformation of the Afar rift from a 3-D velocity field inversion of InSAR and GPS, J. geophys. Res., 119, 8562-8575.

Patriat, P. \& Courtillot, V., 1984. On the stability of triple junctions and its relation to episodicity in spreading, Tectonics, 3, 317-332.

Peltzer, G., Crampé, F., Hensley, S. \& Rosen, P., 2001. Transient strain accumulation and fault interaction in the Eastern California shear zone, Geology, 29, 975-978.

Peltzer, G., Doubre, C. \& Tomic, J., 2007. Micro-deformation and microseismicity in the Makarassou Fault Zone, Afar, AGU Fall Meeting, abstract G13C-04, http://adsabs.harvard.edu/abs/2007AGUFM.G13C.04P.

Quade, J. et al., 2008. The geology of Gona, Afar, Ethiopia,, Geol. Soc. Amer. Spec. Pap., 446, 1-31.

Rosen, P., Hensley, S., Peltzer, G. \& Simons, M., 2004. Updated repeat orbit interferometry package released, EOS, Trans. Am. geophys. Un., 85, 47-47.

Rubin, A.M., 1990. A comparison of rift-zone tectonics in Iceland and Hawaii, Bull. Volc., 52, 302-319.

Ruegg, J.C. \& Kasser, M., 1987. Deformation across the Asal-Ghoubbet Rift, Djibouti, uplift and crustal extension 1979-1986, Geophys. Res. Lett., 14, 745-748.

Saria, E., Calais, E., Altamimi, Z., Willis, P. \& Farah, H., 2013. A new velocity field for Africa from combined GPS and DORIS space geodetic Solutions: contribution to the definition of the African reference frame (AFREF), J. geophys. Res., 118, 1677-1697.

Saria, E., Calais, E., Stamps, D., Delvaux, D. \& Hartnady, C., 2014. Present-day kinematics of the East African Rift, J. geophys. Res., 119, $3584-3600$

Searle, R., 1980. Tectonic pattern of the Azores spreading centre and triple junction, Earth planet. Sci. Lett., 51, 415-434. 
Sichler, B., 1980. La biellette danakile: un modèle pour l'évolution géodynamique de l'Afar, Bull. Soc. Géol. Fr., 22, 925-932.

Sigmundsson, F., 1992. Tectonic implications of the 1989 Afar earthquake sequence, Geophys. Res. Lett., 19, 877-880.

Smittarello, D., Grandin, R., De Chabalier, J.-B., Doubre, C., Déprez, A., Masson, F., Socquet, A. \& Saad, A., 2016. Transient deformation in the Asal-Ghoubbet Rift (Djibouti) since the 1978 diking event: Is deformation controlled by magma supply rates?, J. geophys. Res., 121, doi:10.1002/2016JB013069.

Stab, M., Bellahsen, N., Pik, R., Quidelleur, X., Ayalew, D. \& Leroy, S., 2016. Mode of rifting in magma-rich settings: tectono-magmatic evolution of Central Afar, Tectonics, 35, 2-38.

Stein, S. \& Gordon, R.G., 1984. Statistical tests of additional plate boundaries from platemotion inversions, Earth planet. Sci. Lett., 69, 401-412.

Souriot, T. \& Brun, J.P., 1992. Faulting and block rotation in the Afar triangle: the Danakil "crank arm" model, Geology, 20, 911-914.

Spakman, W. \& Nyst, M., 2002. Inversion of relative motion data for estimates of the velocity gradient field and fault slip, Earth planet. Sci. Lett., 203, 577-591.

Tapponnier, P. \& Varet, J., 1974. La zone de Mak'arassou en Afar: un équivalent émergé des 'failles transformantes' océaniques, C. R. Acad. Sci. Paris, 278, 209-212.

Tapponnier, P., Armijo, R., Manighetti, I. \& Courtillot, V., 1990. Bookshelf faulting and horizontal block rotations between overlapping rifts in southern Afar, Geophys. Res. Lett., 17, 1-4.

Tarantola, A., Ruegg, J.-C. \& Lépine, J.-C., 1979. Geodetic evidence for rifting in Afar: a brittle-elastic model of the behaviour of the lithosphere, Earth planet. Sci. Lett., 45, 435-444.
Tarantola, A., Ruegg, J.-C. \& Lépine, J.P., 1980. Geodetic evidence for rifting in Afar, 2. Vertical displacements, Earth planet. Sci. Lett., 48, 363-370.

Varet, J., 1975. Carte géologique de l'Afar central et méridional, CNRCNRS, 1/500 000 Géotechnip.

Vellutini, P., 1990. The Manda-Inakir Rift, Republic of Djibouti: a comparison with the Asal. Rift and its geodynamic interpretation, Tectonophysics, 172, 141-153.

Vigny, C., Huchon, P., Ruegg, J.-C., Khanbari, K. \& Asfaw, L.M., 2006. Confirmation of Arabia plate slow motion by new GPS data in Yemen, $J$. geophys. Res., 111, B02402, doi:10.1029/2004JB003229.

Vigny, C., de Chabalier, J.-B., Ruegg, J.-C., Huchon, P., Feigl, K.L., Cattin, R. \& Kanbari, K., 2007. Twenty-five years of geodetic measurements along the Tadjoura-Asal rift system, Djibouti, East Africa, J. geophys. Res., 112, B06410, doi:10.1029/2004JB003230.

Wolfenden, E., Ebinger, C., Yirgu, G., Deino, A. \& Ayalew, D., 2004. Evolution of the northern Main Ethiopian rift: birth of a triple junction, Earth planet. Sci. Lett., 224, 213-228.

Wolfenden, E., Ebinger, C., Yirgu, G., Renne, P. \& Kelley, S., 2005. Evolution of the southern Red Sea rift: birth of a magmatic margin, Bull. Geol. Soc. Am., 117, 846-864.

Wright, T.J., Ebinger, C., Biggs, J., Ayele, A., Yirgu, G., Keir, D. \& Stork, A., 2006. Magma-maintained rift segmentation at continental rupture in the 2005 Afar dyking episode, Nature, 442, 291294.

Wu, Y., Jiang, Z., Yang, G., Wei, W. \& Liu, X., 2011. Comparison of GPS strain rate computing methods and their reliability, Geophys. J. Int., 185, 703-717. 